\title{
Six New Genes Required for Production of T-Toxin, a Polyketide Determinant of High Virulence of Cochliobolus heterostrophus to Maize
}

\author{
Patrik Inderbitzin, Thipa Asvarak, and B. Gillian Turgeon \\ Department of Plant Pathology \& Plant-Microbe Biology, Cornell University, 334 Plant Science Bldg., Ithaca, NY 14853, \\ U.S.A.
}

Submitted 18 October 2009. Accepted 30 November 2009.

Southern Corn Leaf Blight, one of the worst plant disease epidemics in modern history, was caused by Cochliobolus heterostrophus race $\mathrm{T}$, which produces T-toxin, a determinant of high virulence to maize carrying Texas male sterile cytoplasm. The genetics of T-toxin production is complex and the evolutionary origin of associated genes is uncertain. It is known that ability to produce T-toxin requires three genes encoded at two unlinked loci, Tox1A and Tox $1 B$, which map to the breakpoints of a reciprocal translocation. DNA associated with Tox1A and Tox1B sums to about 1.2 Mb of A+T rich, repeated DNA that is not found in less virulent race $O$ or other Cochliobolus species. Here, we describe identification and targeted deletion of six additional genes, three mapping to Tox1A and three to Tox1B. Mutant screens indicate that all six genes are involved in $\mathrm{T}$ toxin production and high virulence to maize. The nine known Tox1 genes encode two polyketide synthases (PKS), one decarboxylase, five dehydrogenases, and one unknown protein. Only two have a similar phylogenetic profile. To trace evolutionary history of one of the core PKS, DNA from more than 100 Dothideomycete species were screened for homologs. An ortholog (60\% identity) was confirmed in Didymella zeae-maydis, which produces PM-toxin, a polyketide of similar structure and biological specificity as Ttoxin. Only one additional Dothideomycete species, the dung ascomycete Delitschia winteri harbored a paralog. The unresolved evolutionary history and distinctive gene signature of the PKS (fast-evolving, discontinuous taxonomic distribution) leaves open the question of lateral or vertical transmission.

Southern Corn Leaf Blight (SCLB) was the first plant disease to receive wide coverage in the popular press in the United States (Ullstrup 1972). In 1970, a previously unseen race (race $\mathrm{T}$ ) of the filamentous fungus Cochliobolus heterostrophus caused the worst epidemic in U.S. agricultural history, destroying more than $15 \%$ of the maize crop (Hooker 1974; Ullstrup 1972). During the epidemic, the Chicago Tribune published 37

Current address for P. Inderbitzin: Department of Plant Pathology, University of California, Davis, CA 95616, U.S.A.

Current address for T. Asvarak: Department of Biotechnology, Faculty of Science, Mahidol University, Rama 6 Road, Bangkok 10400, Thailand.

Corresponding author: B. G. Turgeon; E-mail: bgt1@ cornell.edu

* The $\boldsymbol{e}$-Xtra logo stands for "electronic extra" and indicates that six supplementary tables and three supplementary figures are published online. articles on the disease within a period of four months (Ullstrup 1972). The epidemic was due to the then-unknown exquisite sensitivity of the Texas male sterile cytoplasm (Tcms) to race T. Tcms was discovered in the 1940 s and had been incorporated into elite corn inbred lines increasingly throughout the 1960s (Wise et al. 1999). By 1970, it was present in almost all of the hybrid corn in the U.S.

In fact, increased susceptibility of Tcms corn to certain isolates of $C$. heterostrophus had been reported in The Philippines as early as 1961 (Mercado and Lantican 1961) and also in the U.S. (southern Iowa and Illinois) in 1968 (Scheifele et al. 1970; Ullstrup 1970, 1972). The presence of a new race of the fungus was not considered seriously until the epidemic in 1970, when studies on a $C$. heterostrophus isolate obtained from severely diseased corn leaves collected in central Illinois in 1969 were published (Hooker et al. 1970; Lim and Hooker 1971, 1972a and b; Smith et al. 1970). This isolate was designated 'race T' for its high virulence on Tcms and for its ability to produce T-toxin, a metabolite that specifically affects Tcms corn. Prior to $1970, C$. heterostrophus was known as an endemic pathogen of minor economic importance in the U.S., first described in 1925 by Drechsler (1925). This version of the pathogen (race $\mathrm{O}$ ) is mildly virulent on both T- and normal (N)-cytoplasm corn (Hooker et al. 1970; Smith et al. 1970). It is currently unclear whether $C$. heterostrophus race $\mathrm{T}$ evolved around the time of the epidemic or had been 'lurking' in the field for a long time. Regardless of the answer, the vast monoculture of Tcms maize was the perfect host for previously unknown race $\mathrm{T}$. In Tcms corn, T-toxin interacts with the URF13 protein located in the inner mitochondrial membrane (Braun et al. 1990; Levings et al. 1995), causing leakage of small molecules (Matthews et al. 1979) and widespread tissue necrosis (Yoder and Gracen 1975), possibly via apoptosis (Wolpert et al. 2002).

T-toxin is a family of linear polyketides 37 to 45 carbons in length, of which the major component is 41 carbons (Kono et al. 1981). The ability to produce T-toxin is genetically inseparable from high virulence of the fungus on Tcms corn. In crosses between naturally occurring race $O$ and race $T$, all progeny producing T-toxin are highly virulent and all progeny not producing T-toxin are weakly virulent on Tcms corn (Lim and Hooker 1971). This 1:1 segregation of parental phenotypes defines a single genetic locus, designated Toxl (Leach et al. 1982b; Lim and Hooker 1971; Tegtmeier et al. 1982) that controls T-toxin production and high virulence of $C$. heterostrophus race $\mathrm{T}$. However, although early studies supported this simple inheritance pattern, Toxl was subsequently found to be genetically more complex. The first indication of this was the 
discovery that Toxl is inseparable from a reciprocal translocation breakpoint. This possibility was first proposed based on the comparison of nonviable ascospore frequencies in crosses homozygous vs. heterozygous at Toxl (Bronson 1988). The pattern of ascospore abortion suggested that race $\mathrm{T}$ and race $\mathrm{O}$ differ by a reciprocal translocation and that Tox 1 is at or near the breakpoint. This observation was supported by the construction of a restriction fragment length polymorphism (RFLP) map (Tzeng et al. 1992), which revealed a four-armed linkage group, diagnostic of a reciprocal translocation, with Toxl located at the intersection. The linkage group consists of a pair of race $\mathrm{O}$ chromosomes (6 and 12) and a pair of race $\mathrm{T}$ chromosomes $(6 ; 12$ and $12 ; 6)$ that are reciprocally translocated with respect to the race O pair (Tzeng et al. 1992). These findings demonstrated that Toxl was not a simple, single, Mendelian character and that the conclusions from the earlier genetic analyses were misleading.

Although RFLP mapping placed Toxl at the intersection of the four-armed linkage group, it did not reveal its exact chromosomal location, i.e., which translocated chromosome it was on or whether it was on both. The answer to this question was not available until it became possible to do genetic analysis of toxin production with tagged tox $\mathrm{x}^{-}$mutants of a progenitor Tox $1^{+}$strain. Until this time, all genetic analyses had relied on crosses between naturally occurring race $\mathrm{O}$ and race $\mathrm{T}$ strains, which, as noted above, are distinguished by a reciprocal translocation intimately associated with toxin production. The translocation complicates genetic analysis, since the pair of chromosomes carrying Toxl is heterozygous with respect to the pair in race O. Crosses between induced, tagged, tox ${ }^{-}$mutants (i.e., in a Tox $1^{+}$genetic background) and a wild-type race $\mathrm{O}$ tester (the translocated chromosomes are heterozygous) showed that all induced tox ${ }^{-}$mutations mapped at the previously defined Toxl locus, since all progeny from these crosses were tox ${ }^{-}$. Crosses between the tox ${ }^{-}$mutants (Tox $1^{+}$genetic background) and a wild-type race $\mathrm{T}$ tester are between isogenic strains that differ only by the mutation at Toxl and, by necessity, at MAT1. This type of cross confirmed that each mutation was at a single site, since progeny segregated $1: 1$ for toxin production. Up to this point, these data led to the same conclusion as race $\mathrm{O}$ by race $\mathrm{T}$ crosses i.e., that Toxl is indeed a single locus. However, when tox ${ }^{-}$mutants were crossed to each other (these crosses are also between isogenic strains differing only by the mutation at Toxl and at MAT), the major hypothesis that Toxl is a single locus collapsed. Progeny of a cross between one particular mutant and any of the other induced mutants were $25 \% \mathrm{Tox}^{+}$, indicating that the mutation in the first mutant strain was not linked to the others. Furthermore, heterokaryons between an auxotroph of the unique mutant and different auxotrophs of any of the other induced mutants were all found to produce about as much T-toxin as a control formed by two wild-type race $\mathrm{T}$ strains, indicating that the defects in the induced mutants could be complemented by the nucleus of the unique mutant (Kodama et al. 1999).

Physical mapping of gel-separated chromosomes of the tagged Tox $^{-}$mutants, using probes to the selectable markers employed to generate the mutations, confirmed that Toxl is not a single locus. The majority of the induced mutations were located on translocated chromosome $12 ; 6$, however, one mutation was located on chromosome $6 ; 12$, the other chromosome involved in the reciprocal translocation (Kodama et al. 1999). Thus, after about 25 years of data that suggested Toxl is a single locus, it was demonstrated that Toxl is on two different chromosomes and that the two loci map to the chromosomes that are reciprocally translocated (Bronson 1988; Tzeng et al. 1992) in race T (i.e., chromosomes 6;12 and 12;6) with respect to the race $\mathrm{O}$ counterparts (chromosomes 6 and 12). Toxl be- haves like a single Mendelian element because these two chromosomes must cosegregate during meiosis whenever a cross is heterozygous at Toxl (i.e., race $\mathrm{O} \times$ race $\mathrm{T}$ ) (Kodama et al. 1999; Turgeon et al. 1995). When they do not cosegregate, ascospore progeny are nonviable due to chromosome segment duplications and deletions. When crosses are homozygous, (i.e., tox ${ }^{-}$mutant of a Tox $I^{+}$strain by another such mutant) the complexities of reciprocal translocation genetics are eliminated and the two translocated chromosomes segregate independently. To reflect the unique genetic organization of Toxl, the two loci were designated ToxlA and ToxlB (Kodama et al. 1999).

In addition to the translocation, Toxl is associated with a large insertion and highly repeated DNA (Chang and Bronson 1996; Kodama et al. 1999; Tzeng et al. 1992). Evidence for this includes the following. i) The total size of translocated chromosomes $6 ; 12$ and $12 ; 6$ in race $\mathrm{T}$ sums to about $1.2 \mathrm{Mb}$ more than the sum of the sizes of chromosomes 6 and 12 in near-isogenic race $O$. Since the strains used for this analysis are highly inbred but heterozygous at Toxl, the inserted DNA is predicted to be located at or near Toxl. ii) Half of the RFLP probes mapping within $4 \mathrm{cM}$ of Toxl are repetitive, in contrast to only approximately $4 \%$ repetitive probes in the remainder of the race $\mathrm{T}$ genome (Chang and Bronson 1996; Tzeng et al. 1992; Yoder et al. 1994). Cloning of genes from the two Toxl loci and the architecture of the scaffolds carrying Toxl-associated genes in the race $\mathrm{T}$ genome assembly (Torrey Mesa Research Institute (TMRI)/Syngenta) confirmed that the Toxl genes are, indeed, embedded in highly repeated A+T-rich DNA (Turgeon and Baker 2007). These genes are different on scaffolds and are not closely linked or 'clustered' as are many genes involved in production of secondary metabolites. iii) The genes are completely missing in race O (Baker et al. 2006; Rose et al. 2002; Yang et al. 1996).

The evolutionary origin of race $\mathrm{T}$ remains unresolved. Not only are Toxl genes absent in race O (Baker et al. 2006; Rose et al. 2002; Yang et al. 1996), they are also absent from closely related Cochliobolus species and other genera (Rose 1996). Based on these data as well as codon usage, $\mathrm{A}+\mathrm{T}$ content and genetic location of the Toxl locus, an origin by horizontal transfer was suggested by Yang and associates (1996) and by Wise and associates (1999) but was not established decisively.

Four genes mapping to Toxl have been reported to date. At Tox $1 A$ are two polyketide synthase-encoding genes, $P K S 1$ and PKS2 (Baker et al. 2006; Yang et al. 1996), and at Tox1B, the linked DEC1 and RED1 (Rose et al. 2002). Deletion of PKS1, $P K S 2$, and $D E C 1$ demonstrated that they are required for Ttoxin synthesis and high virulence to Tcms corn (Baker et al. 2006; Rose et al. 2002; Yang et al. 1996), whereas deletion of RED1 had no apparent effect on T-toxin production (Rose et al. 2002).

There is evidence for additional genes for T-toxin biosynthesis. Complementation of a strain with a $75-\mathrm{kb}$ deletion that encompassed the Decl locus, with DNA carrying a functional DECl gene, did not restore T-toxin production (Zhu 1999), suggesting that more genes were necessary from Tox $1 B$. In addition, the race $\mathrm{T}$ genome assembly revealed previously undescribed genes adjacent to DEC1/REDI at Tox $1 B$ and to $P K S 2$ at ToxlA that were absent in race $\mathrm{O}$ (Turgeon and Baker 2007); as noted above, absence in race $\mathrm{O}$ is a feature common to all required Toxl genes described to date.

To search for additional genes required for T-toxin biosynthesis, we queried the race $\mathrm{T}$ genome assembly with the DNA sequences of known Toxl genes and functionally characterized novel genes that were physically linked. We also reanalyzed a race $\mathrm{T} /$ race $\mathrm{O}$ comparative cDNA expression dataset described by Baker and associates (2006) and Li and associates (2002). 
Here, we report that six additional genes (including previously reported $R E D 1$ ), mapping to both Tox $1 A$ and Tox $1 B$ are required for T-toxin production. In addition, gene candidates were evaluated for their phylogenetic relationships and possible evolutionary origins.

\section{RESULTS}

Five new genes at Tox $1 A$ and Tox1B.

The proprietary $C$. heterostrophus race $\mathrm{T} \mathrm{C} 4$ genome, sequenced by Celera for TMRI/Syngenta was queried with the known Toxl genes PKS1, PKS2, DEC1, and RED1. Notably, the race $\mathrm{T}$ genome scaffolds (4FP, 4LU, 3PL) carrying these known Toxl genes were the smallest scaffolds in the genome assembly $(23,099,30,397$, and 43,533 bp, respectively). Detailed examination revealed that only $4 \mathrm{LU}$ and $3 \mathrm{PL}$ carried candidate new Tox 1 genes (LAM1, RED2, RED3) (Fig. 1). All three are dehydrogenases. $L A M 1$, encoding a putative 3hydroxyacyl-CoA dehydrogenase (Pfam 00725), is located 2,342 bp upstream of PKS2 and, thus, is at ToxlA (Fig. 1). The $L A M 1$ open reading frame (ORF) is predicted to be $1,476 \mathrm{bp}$ in length with a 53-bp intron. RED2 and RED3 are located $1,961 \mathrm{bp}$ downstream of REDI and thus are at ToxlB (Rose et al. 2002). Both encode putative short-chain dehydrogenases (Pfam 00106), while REDI encodes a putative zinc-binding dehydrogenase (Pfam 00107). The RED2 and RED3 ORF are 842 and 591 bp in length, respectively, separated by $5,037 \mathrm{bp}$. RED2 has one 44-bp intron.

In addition to identifying candidate Tox 1 genes by proximity to known Toxl genes, as described above, the ligation specificity-based expression analysis display (LEAD) dataset, a race
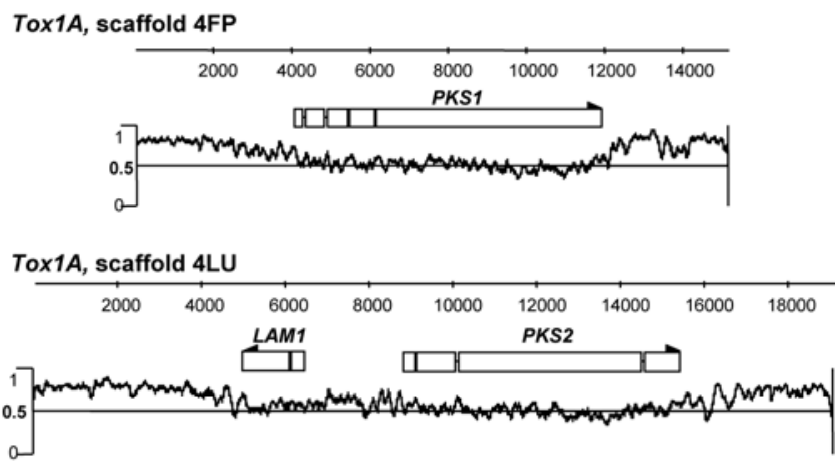

Tox1A, contig OXI1/TOX9

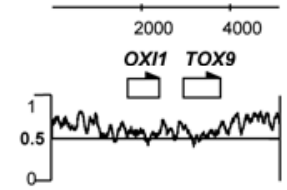

Tox1B, scaffold 3PL

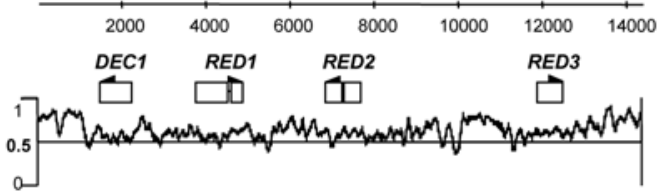

Fig. 1. Toxl scaffold gene maps. Three scaffolds are associated with Tox 1A: 4FP carrying one gene, PKS1; 4LU carrying two genes, PKS2 and LAM1; and OXI1/TOX9 carrying OXI1 and TOX9. One scaffold, 3PL, maps to Tox $1 B$ and carries four genes, DEC1, RED1, RED2, and RED3. Scale above each map is in kilobases. Open boxes indicate gene open reading frames and interruptions indicate introns. Scale to the left of each map is $\% \mathrm{~A}+\mathrm{T}$, with a value of ' 1 ' indicating $100 \% \mathrm{~A}+\mathrm{T}$. Note high $\mathrm{A}+\mathrm{T}$ content in noncoding regions.
O/race T differential cDNA dataset reported by Baker and associates (2006), was reanalyzed for race $\mathrm{T}$-specific gene products, a signature for association with T-toxin production. Two new, linked genes were found. The first, $O X I 1$, encodes a putative short-chain dehydrogenase (Pfam 00106), like RED2 and RED3, whereas the second, TOX9, has no known homology. OXI1 and TOX 9 are 699 and 837 bp in length, respectively, situated 515 bp apart; both lack introns (Fig. 1).

\section{Resequencing scaffolds, closing sequencing gaps, and} extending sequence coverage of Tox 1 -associated regions.

Retrieved scaffolds (4FP, 4LU, 3PL) from the TMRI/Syngenta/Celera assembly were checked for correct contig assembly and sequence quality by polymerase chain reaction (PCR) amplification, using primers matching known regions (data not shown). Gaps between contigs were filled by sequencing off of contigs, combined with incorporation of previously sequenced associated genes deposited in GenBank (data not shown). Using these approaches, we could confirm only 15,139 bp of scaffold 4FP (ToxlA) carrying PKS1; this included 1,760 bp from GenBank record U68040 (position 10,135 to 11,894). Scaffold 4FP extended previously identified sequence carrying PKS1 (Yang et al. 1996) by 2,761 and $2,553 \mathrm{bp}$, at the 5 and $3^{\prime}$ ends, respectively, and differed from GenBank record U68040 at five positions, in one case, resulting in an amino-acid change. Confirmed sequence of scaffold 4LU (ToxIA), carrying PKS2 and LAM1, was 19,137 bp and incorporated 2,980 bp from GenBank record DQ186598 (Baker et al. 2006) at position 9,903 to 12,881. The 5 and $3^{\prime}$ ends of GenBank sequence DQ186598 were extended by 8,851 and $3,649 \mathrm{bp}$, respectively. Confirmed sequence of scaffold 3PL (ToxlB) with DEC1, RED1, RED2, and RED3 was $14,415 \mathrm{bp}$ and included 2,216 bp from GenBank record AF525909 at positions 1 to 639 and 3,248 to 4,823. At the 3' end, $8,739 \mathrm{bp}$ is new coverage with respect to GenBank sequence AF525909 (Rose et al. 2002). This sequence differed at multiple positions in the noncoding regions from GenBank record AF525909 (data not shown). Sequences corresponding to 4FP, 4LU, 3PL were deposited as accession numbers U68040.3, DQ186598.2, and AF525909.2.

The final length of the contig carrying OXI1 and TOX9 from the LEAD dataset was 5,129 bp and was obtained by chromosome walking starting from TOX9 (accession number FJ943499).

\section{Tox1 genes are embedded in $\mathrm{A}+\mathrm{T}$ rich sequence.}

As reported previously for PKSI (Yang et al. 1996) and PKS2 (Baker et al. 2006), the Tox1 region has a bias towards $\mathrm{A}+\mathrm{T}$ nucleotides (Fig. 1) outside coding regions. Note, for example, that scaffold 4FP carrying PKS1 is approximately $50 \%$ $\mathrm{G}+\mathrm{C}$ for the $P K S 1$ coding region but rises to an average of approximately $75 \% \mathrm{~A}+\mathrm{T}(25 \% \mathrm{G}+\mathrm{C})$ in the 5 and $3^{\prime}$ flanks of PKS1 (approximately 4,000 and 3,000 bp, respectively). Similarly scaffold $4 \mathrm{LU}$, carrying $P K S 2$ (approximately $50 \% \mathrm{G}+\mathrm{C}$ ) and $L A M 1(46 \% \mathrm{G}+\mathrm{C}$ and $54 \% \mathrm{~A}+\mathrm{T})$ is $59 \% \mathrm{~A}+\mathrm{T}$ between the two genes and 67 and $74 \% \mathrm{~A}+\mathrm{T}$ in the $3^{\prime}$ flanking regions of both genes.

\section{New Tox 1 genes are absent in race 0 .}

As for the previously known Toxl genes (Baker et al. 2006; Rose et al. 2002; Yang et al. 1996), none of the new Toxl genes is present in race $\mathrm{O}$. This was initially determined by PCR screening of race $\mathrm{O}$ DNA using specific primers to $L A M 1$, $R E D 2, R E D 3, O X I 1$, and $T O X 9$, respectively. When the race $\mathrm{O}$ genome sequence became available from the Joint Genome Initiative (JGI) Cochliobolus heterostrophus C5 website, blastn queries with the Toxl genes failed to show matches. 
Deletion of candidate Tox 1 genes and consequences for T-toxin production.

The five new Tox1 genes (LAM1, RED2, RED3, OXI1, TOX9) and previously known REDl (Rose et al. 2002) were deleted singly and in the following combinations RED1/RED2, RED1/RED3, RED2/RED3, RED1/RED2/RED3, and OXI1/ TOX 9. Four individual transformants per transformation construct were collected. Deletion of each gene or gene set was confirmed by PCR screening (Supplementary Figs. 1, 2, and 3). The genotype of each transformant type and all strains used in this manuscript are shown in Table 1.

The microbial assay (Ciuffetti et al. 1992) was used to investigate the effect of Toxl gene deletions on T-toxin production of the 11 deletion mutant types (Fig. 2). No halos were present in red1;red2, red2;red3, or red1;red2;red3, tox9, oxil;tox9, indicating that T-toxin production was absent or not detectable in the microbial assay. For the remaining types of transformant (red1, red2, red3, red1; red3, oxil, lam 1), T-toxin production was significantly reduced but not eliminated. redl and oxil mutants were the least reduced (most leaky), while the others had clear small halos $($ red 2 , red3) in all four replicates or an occasional halo in one or more of the replicates (lam1, red1;red3). Thus, all new candidate Toxl genes are involved in T-toxin production, but in all single mutant cases except for tox 9 , a combination of gene deletions was required to completely eliminate it.

\section{Virulence of Tox1-deletion strains to corn.}

In general, virulence results from the corn assays correlated with the bacterial T-toxin screens, although small differences in the former are more difficult to assess. Control race $\mathrm{T} \mathrm{C} 4$ and race O C5 strains were used for both the spray and whorl inoculations. As expected, both race $\mathrm{T}$ and race $\mathrm{O}$ caused symptoms; however, leaves from race $\mathrm{T}$ on $\mathrm{Tcm}$ s were the most affected. Leaves showed yellow streaking characteristic of T-toxin production (Fig. 3, arrows) and were shriveled brown-gray (Fig. 3 , top left). The race $\mathrm{O}$ control was equally pathogenic on $\mathrm{N}$ and $\mathrm{T}$ cytoplasm and without yellow streaks associated with toxin production (Fig. 3). The previously described tight tox $1^{-}$ mutants ( $p k s 1, p k s 2$, and decl [Baker et al. 2006; Rose et al. 2002; Yang et al. 1996]) were like control race O strain C5 on both Tcms and N-cytoplasm corn (Fig. 3 second row).

For the new mutants, no T-toxin symptoms were observed when red2;red3, red1;red2;red 3 , tox 9 , and tox9;oxil strains were spray-inoculated on susceptible corn (Fig. 4), as in the bacterial assays. Deletion strains oxil and redl, which were reduced but still produced considerable T-toxin in the microbial assay, yielded leaves that were shriveled and gray in both the spray and whorl inoculations and showed yellow streaking in the whorl assay characteristic of T-toxin production, similar to the race T control strain (Figs. 3 and 4). 'Leaky' deletion strains (red 2, red 3$)$ that produced smaller than wild-type halos, indicating that they produced reduced amounts of T-toxin, displayed less pronounced gray streaking with both types of inoculation and yellow streaking on most leaves in the whorl assay, characteristic of T-toxin production. laml mutants produced an occasional halo in the microbial assay and showed some gray lesions and yellow streaking in the whorl assay. red1; red $3 \mathrm{mu}$ tants produced an occasional halo in the microbial assay and some gray lesions in the spray inoculation but no yellow streaking in the whorl assay. For red1;red2, no halos or gray lesions were apparent; however, occasional yellow streaking typical of T-toxin production was seen on a small number of leaves. One of the leaves inoculated (whorl) with a tox 9 mutant showed a yellow streak indicative of T-toxin production (Fig. 3). All other assays, however, showed typical race $\mathrm{O}$ symptoms and no halos were evident in the microbial assay (Figs. 2, 3, and 4).
We conclude that the products of all new genes are involved in T-toxin production and that the products of the three $R E D$ genes likely have redundant functions such that only when all three or when $R E D 2$ and $R E D 3$ are deleted together is a complete tox ${ }^{-}$strain produced. The tox 9 mutation combined with the very leaky oxil mutation results in a strain devoid of toxin production, suggesting that the product of TOX9 is epistatic to that of $O X I 1$.

\section{Mapping Tox1 genes.}

Three of the new Toxl genes, LAM1, RED2, and RED3, were in close proximity to known Toxl genes. Thus, it was clear that LAM1 mapped to ToxlA, and RED2 and RED3

Table 1. All strains used in this study

\begin{tabular}{|c|c|}
\hline Strain $^{a}$ & Genotype \\
\hline PC4 (C4) & TOX1;MAT1-2 \\
\hline PC5 (C5) & tox $1 ; M A T 1-1$ \\
\hline PC8 (1326-R-5) & pks1;MAT1-1;Hyg $B^{R}$ \\
\hline $\mathrm{C} 4.910$ & pks2;MAT1-2;Hyg $B^{R}$ \\
\hline PC13 (1213-R-65) & dec1;MAT1-1;HygB $B^{R}$ \\
\hline PC90 (C9) & TOX1;MAT1-1 \\
\hline PC157 & red1;MAT1-2;HygB $B^{R}$ \\
\hline PC158 & red1;MAT1-2;HygB ${ }^{R}$ \\
\hline PC159 & red1;MAT1-2;HygB ${ }^{R}$ \\
\hline PC187 & red1;MAT1-2;HygB ${ }^{R}$ \\
\hline PC161 & $\operatorname{red} 2 ; M A T 1-2 ; H y g B^{R}$ \\
\hline PC162 & $\operatorname{red} 2 ; M A T 1-2 ; H y g B^{R}$ \\
\hline PC182 & $\operatorname{red} 2 ; M A T 1-2 ; H y g B^{R}$ \\
\hline PC183 & $\operatorname{red} 2 ; M A T 1-2 ; H y g B^{R}$ \\
\hline PC165 & red3;MAT1-2;HygB ${ }^{R}$ \\
\hline PC166 & red3;MAT1-2;HygB ${ }^{R}$ \\
\hline PC274 & red3;MAT1-2;HygB ${ }^{R}$ \\
\hline PC275 & red3;MAT1-2;HygB $B^{R}$ \\
\hline PC263 & red1;red $2 ; M A T 1-2 ; H y g B^{R}$ \\
\hline PC264 & red1;red $2 ; M A T 1-2 ; H y g B^{R}$ \\
\hline PC265 & red1;red $2 ; M A T 1-2 ; H y g B^{R}$ \\
\hline PC266 & red1;red $2 ;$ MAT1-2;Hyg $B^{R}$ \\
\hline PC297 & red1;red3;MAT1-2;HygB ${ }^{R} ;$ bar $^{R}$ \\
\hline PC298 & red1;red3;MAT1-2;HygB ${ }^{R} ;$ bar $^{R}$ \\
\hline PC300 & red1;red3;MAT1-2;HygB ${ }^{R} ;$ bar $^{R}$ \\
\hline PC303 & red1;red3;MAT1-2;HygB ${ }^{R} ;$ bar $^{R}$ \\
\hline PC268 & red2;red3;MAT1-2;Hyg $B^{R}$ \\
\hline PC269 & red2;red3;MAT1-2;HygB ${ }^{R}$ \\
\hline PC270 & red2;red3;MAT1-2;Hyg $B^{R}$ \\
\hline PC271 & $\operatorname{red} 2 ;$ red3;MAT1-2;Hyg $B^{R}$ \\
\hline PC110.1 & red1;red2;red3;MAT1-2;HygB $B^{R}$ \\
\hline PC111.2 & red1;red 2;red3;MAT1-2;Hyg $B^{R}$ \\
\hline PC206 & red1;red2;red3;MAT1-2;HygB ${ }^{R}$ \\
\hline PC208 & red1;red2;red3;MAT1-2;HygB $B^{R}$ \\
\hline PC185 & oxi1;MAT1-2;Hyg $B^{R}$ \\
\hline PC224.1 & oxi1;MAT1-2;HygB ${ }^{R}$ \\
\hline PC225.1 & oxi1;MAT1-2;Hyg $B^{R}$ \\
\hline PC226.1 & oxi1;MAT1-2;HygB ${ }^{R}$ \\
\hline PC249 & tox9;MAT1-2;Hyg $B^{R}$ \\
\hline $\mathrm{PC} 251$ & tox $9 ; M A T 1-2 ; H y g B^{R}$ \\
\hline PC252 & tox $9 ; M A T 1-2 ; H y g B^{R}$ \\
\hline PC254 & tox $9 ; M A T 1-2 ; H y g B^{R}$ \\
\hline PC44 & oxi1;tox9; MAT1-2;HygB $B^{R}$ \\
\hline PC246 & oxi1;tox9;MAT1-2;HygB $B^{R}$ \\
\hline PC248 & oxi1;tox9;MAT1-2;Hyg $B^{R}$ \\
\hline PC256 & oxi1;tox $9 ; M A T 1-2 ; H y g B^{R}$ \\
\hline PC282 & lam1;MAT1-2;Hyg $B^{R}$ \\
\hline PC284 & lam1;MAT1-2;Hyg $B^{R}$ \\
\hline PC286 & lam1;MAT1-2;HygB ${ }^{R}$ \\
\hline PC287 & lam1;MAT1-2;Hyg $B^{R}$ \\
\hline
\end{tabular}

${ }^{\mathrm{a}}$ C4 = ATCC 48331 (Leach et al. 1982a); C5 = ATCC 48332 (Leach et al. 1982a); PC8 (1326-R-5) is an ascospore progeny from a cross of race $\mathrm{T}$ wild-type strain C9 $(M A T 1-1) \times$ race T strain C4 (MAT1-2) carrying a deletion of PKS1 (Zhu 1999); C4.910 (Baker et al. 2006); PC13 = 1213R-65 (Rose et al. 2002); PC90 (C9) is a member of a highly inbred line of Cochliobolus heterostrophus strains (Leach et al., 1982a). All other strains were constructed in this work. 
mapped to Tox $1 B$ (Fig. 1). The location of $O X I 1$ and TOX9 was unknown. Therefore, crosses to tester wild-type $T o x 1^{+}$and Tox $1^{-}$strains and to known tox $1 A$ and tox $1 B$ mutants were used to determine their genetic location (Table 2). Progeny of crosses between either oxil $1^{-}$or tox $9^{-}$strains $\left(H y g B^{R}\right)$ and toxlA mutant strain 1326-R-5 (PC8: pksl;HygB ${ }^{R}$;MAT1-1) were $100 \% \operatorname{HygB}^{\mathrm{R}}$ and did not produce T-toxin, suggesting linkage of both $O X I 1$ and TOX9 to ToxIA (Table 2). In contrast, when crossed to toxlB mutant strain, 1213-R-65 (PC13: decl;Hyg $\left.B^{R} ; M A T 1-1\right)$ approximately one quarter of the progeny were sensitive to hygromycin B and produced T-toxin, indicating independent segregation of $O X I 1$ and TOX9 from ToxlB. These data show that OXII and TOX9 are at ToxlA. The physical location with respect to PKS1 and $P K S 2$ is unknown, however, as crosses to pks 1 strain 1326-R-5 (PC8) did not result in any recombinants. No crosses to $p k s 2$ or to lam 1 strains were done, but PCR efforts to link the scaffold carrying these genes to the $O X I 1 / T O X 9$ contig were unsuccessful, as were efforts to link the contig to the scaffold carrying PKSI (data not shown). Note that the physical location of $P K S 1$ and $P K S 2$ is also unknown.

The other three new Toxl genes, LAM1, RED2 and RED3 were all in close proximity to known genes at ToxlA and Tox $1 B$, and results from crosses were as expected (Table 2). For each mutant strain, crosses to a strain deleted for a Toxl gene at the opposite Toxl locus resulted in an approximately $3: 1$ ratio of $\mathrm{hygB}^{\mathrm{r}} / \mathrm{hygB}^{\mathrm{s}}$, indicating genetic independence. Crosses to tester strains deleted for a Toxl gene at the same Toxl locus were not done for these strains, except for laml strains. Crosses to pks 1 strain 1326-R-5 (PC8) did not result in any recombinant progeny, confirming data by Baker and associates (2006) regarding genetic linkage of $P K S 1$ and $P K S 2$ (and LAM1) at ToxlA. Note again that the physical linkage between $P K S 1$ and $P K S 2$ loci is unknown.

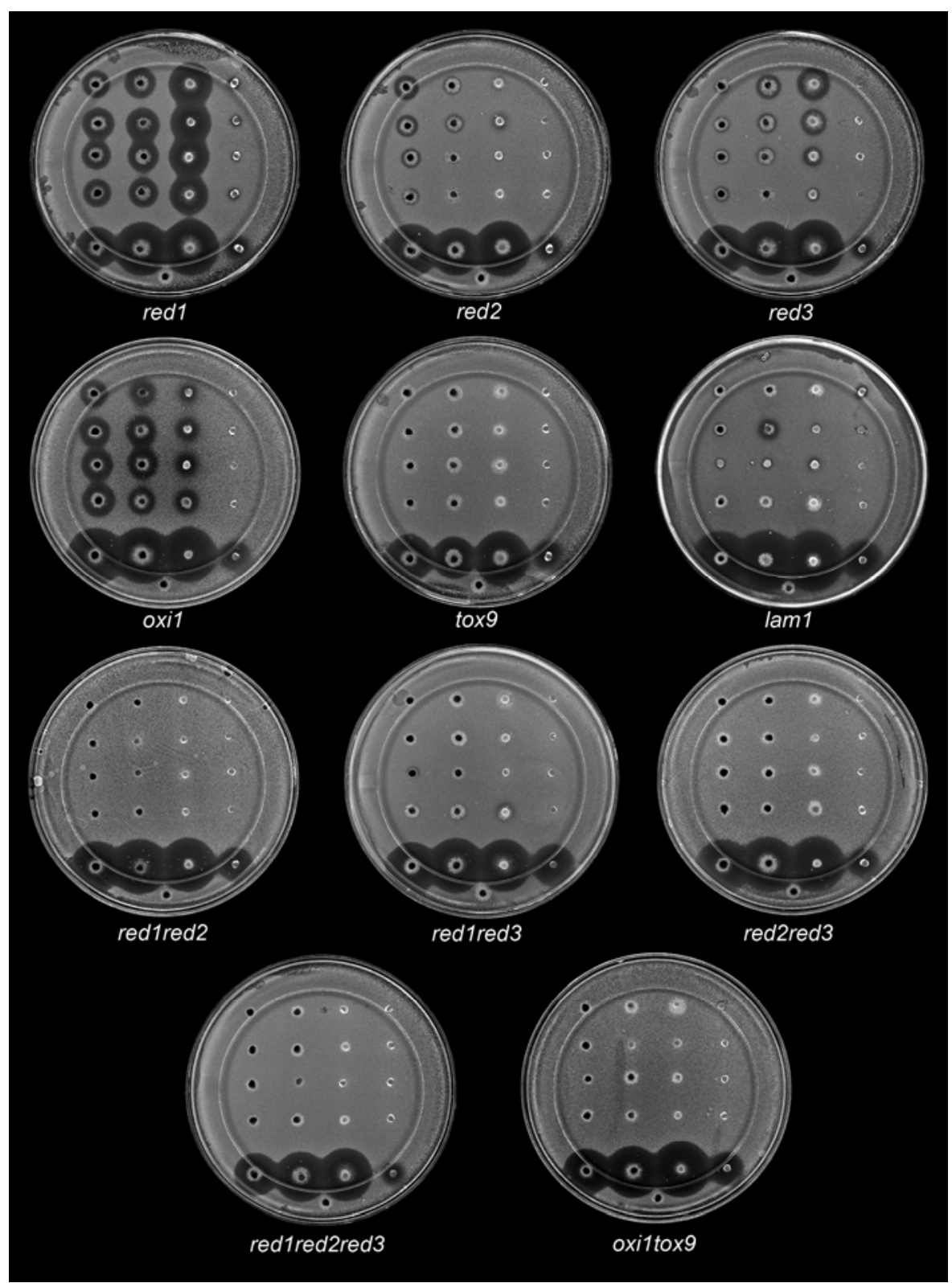

Fig. 2. Images of microbial assay plates for T-toxin production. Plates were spread with Escherichia coli cells carrying the URF13 gene. Plugs of each fungal strain were placed mycelium side down on the plates and were incubated overnight. Clear area (halo) indicates T-toxin production and killing of $E$. coli cells. On each plate, the bottom single plug is race $\mathrm{O}$, Tox ${ }^{-}$control (no halo). Second row from bottom is race $\mathrm{T}$, Tox ${ }^{+}$control (halos). Top four rows in all cases are four replicates of the mutant strain indicated. From left to right in each row are plugs of mycelium taken from 2,1 , and $0 \mathrm{~cm}$ from the edge of the colony and $1 \mathrm{~cm}$ out from the colony edge (in the medium). 

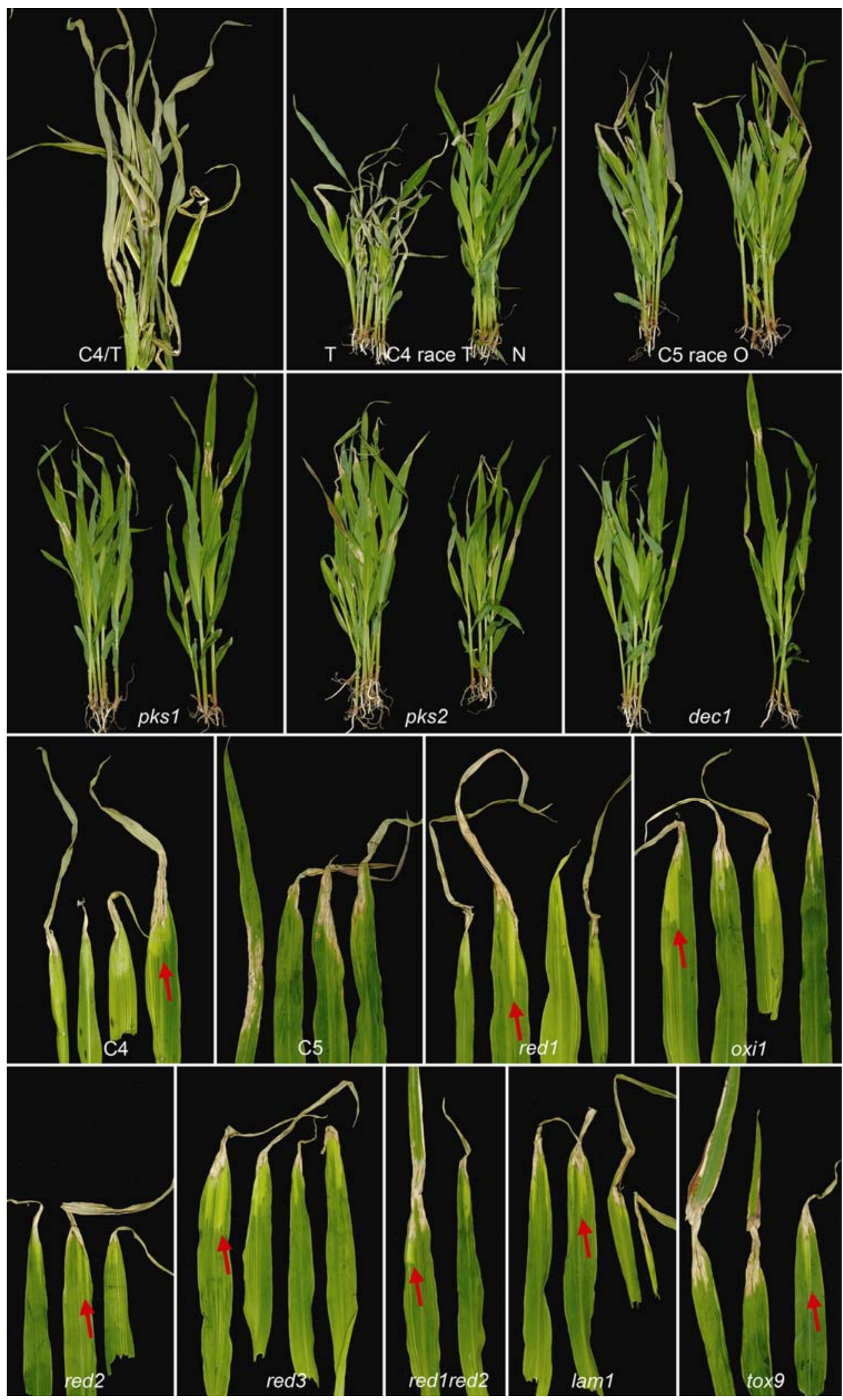

Fig. 3. T-toxin symptoms on maize leaves from whorl inoculation assays. Top two rows show all leaves from T-toxin susceptible T-cytoplasm (left in each panel or alone in top left panel) and T-toxin resistant N-cytoplasm (right in each panel) maize inoculations with control race $\mathrm{T}$ (C4) or race $\mathrm{O}$ (C5) strains (top row) or T-toxin minus $p k s 1$, pks2, or $\operatorname{decl}$ race T mutant strains (second row). Note that race T on T-cytoplasm leaves (top row, middle) are shorter and more shriveled than leaves inoculated with race $\mathrm{O}$ (top row, right) or the T-toxin minus mutant strains (second row), which are like inoculations with race $\mathrm{O}$ (top row, right panel). Left panel, top row is a magnified image of T-cytoplasm leaves inoculated with race T. Note gray, shriveled aspect. Bottom two rows are individual leaves from T-cytoplasm inoculations with the control or mutant strains indicated. Red arrows indicate yellow streaking, the classic T-toxin symptom. Control race $\mathrm{O}$ strains have no such symptom. 
Control crosses to race $\mathrm{O}$ strains $\mathrm{C} 5$ and $\mathrm{C} 9$ were also performed, resulting in 1:1 segregation of hygB ${ }^{\mathrm{R}} / \mathrm{hygB}^{\mathrm{S}}$ (Table 2). This is indicative of a single integration event of the deletion constructs carrying the selectable marker.

For unknown reasons, the number of progeny producing $\mathrm{T}$ toxin in red 2 crosses to ToxlA mutant PC8 did not match the number of hygromycin B-sensitive (wild-type) progeny (Table 2).

\section{Screening for Tox1 gene in isolates of other species.}

DNA from 101 Dothideomycete strains representing approximately 90 different species (Supplementary Table 4) were screened for the presence of PKS1 with PCR primer pairs (Supplementary Table 5) designed to conserved regions of $C$. heterostrophus race T and Didymella zeae-maydis PKS1 functional domains (GenBank accessions U68040 and AY495642). Only one of the 101 strains had a match. Primer pair ERf/ERr targeting the PKS1 enoyl reductase (ER) domain resulted in the discovery of a match to PKS1 in Delitschia winteri PC60. A strong band of expected size (170 bp) was evident with DNA of this isolate. Preliminary phylogenetic analyses showed that the Delitschia winteri sequence clustered with race $\mathrm{T}$ and Didymella zeae-maydis $P K S 1$ genes. Additional sequence was obtained in both directions from the ER domain, using consecutive rounds of chromosome walking (not shown), resulting in a 12,845-bp fragment that was sequenced in both directions. The Delitschia winteri PKS1 gene is predicted to be $7,773 \mathrm{bp}$ in length with five introns, encoding a putative protein of 2,591 amino acids. $\mathrm{G}+\mathrm{C}$ content of $D w P K S 1$ is $52.8 \%$ and the flanking regions are not $\mathrm{A}+\mathrm{T}$ rich (accession number FJ943504).

PCR screening of DNA from 15 Cochliobolus and Bipolaris species for the remaining Toxl genes resulted in no positive fragments (data not shown) and, thus, no homologs.

\section{Phylogenetic analyses.}

Phylogenetic analyses were performed, using the conserved domains of Tox 1 proteins to find the closest relatives as described below. Subtrees showing the topologies around the Tox 1 protein domains are shown in Figure 5. It is striking that, except for $C$. heterostrophus PKS1 and possibly ChRED2/MzmRED1, there were no orthologs to any of the Toxl domains. In addition, although all genes are involved in T-toxin biosynthesis, none of their alliances is similar, even for genes on the same scaffold,
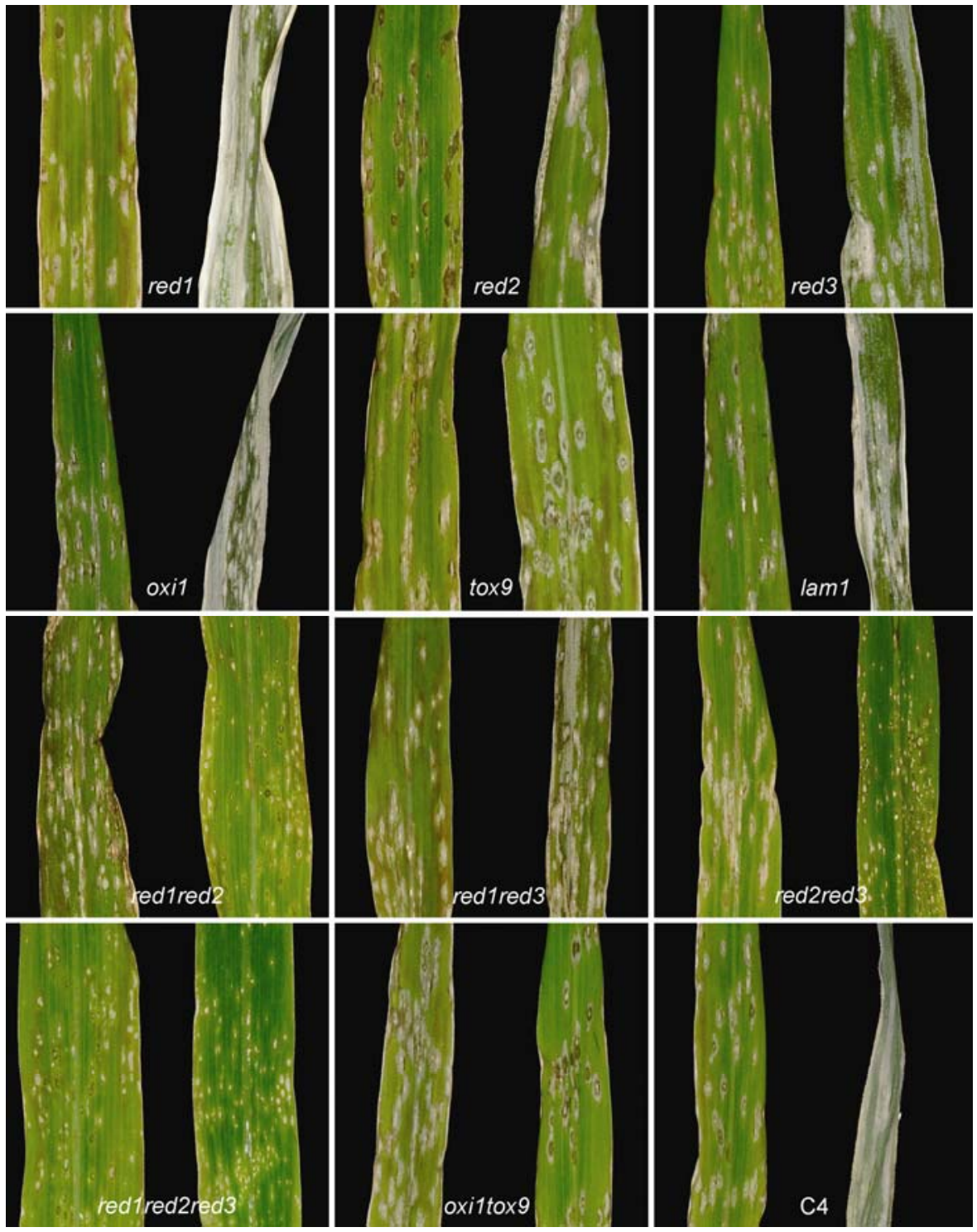

Fig. 4. Disease symptoms on representative maize leaves from spray-inoculation assays. In each case, the left leaf is T-toxin resistant N-cytoplasm, the right is T-toxin susceptible T-cytoplasm, corn. Strains used for inoculation are indicated at the bottom of each panel. Control race T is at lower right. Leaves showing T-toxin symptoms tend to have gray lesions. For some mutants, color varies and size of lesion is reduced (e.g., red2red3, red1 red2red3). 
except for ChRED2 and ChRED3. PKS1, PKS2, RED1, RED2, and RED3 group with other Dothideomycete sequences, while TOX9 groups with Eurotiomycetes and OXI1 with a gene from Pichia pastoris. DEC1 and LAM1 have no close matches.

The closest match to ChPKS1 $(50 \% \mathrm{G}+\mathrm{C})$, the central enzyme and only gene on scaffold 4FP, remains to Didymella zeae-maydis PKS1 (55\% G+C) (M. zeae-maydis), as reported earlier (Kroken et al. 2003). When used as GenBank blast queries, the closest match to these two polyketide synthases (PKS) was to a Eurotiomycete PKS (XP_002485355, 50\% G+C) in Talaromyces stipitatus. Delitschia winteri PKS1 (52\% G+C), identified by PCR in the Dothideomycete DNA collection, was the closest match to the same T. stipitatus PKS. Both of the latter were sister to ChPKS1 and MzmPKS1 from Didymella zeae-maydis. A second T. stipitatus PKS (XP_002482833, 52\% $\mathrm{G}+\mathrm{C})$ and PKS7 (52\% G+C) from C. heterostrophus also fell in this group (Fig. 5).

On scaffold 4LU, PKS2, also essential for T-toxin biosynthesis, grouped with a Phaeosphaeria nodorum PKS with only $76 \%$ support, possibly indicative of a paralogous relationship. The two were sister to various Dothidiomycete and Eurotiomycete PKS. LAM1, adjacent to $P K S 2$, had no close matches. In general, LAM1 grouped with non-Dothideomycete, Eurotiomycete proteins.

C. heterostrophus RED2 and RED3, on scaffold 3PL, grouped with Didymella zeae-maydis MzmRED1, which is essential for PM-toxin production (Yun et al. 1998). MzmRED1 and ChRED2 were monophyletic with $87 \%$ support, confirming earlier results (Yun 1998). Neither C. heterostrophus RED1 nor DEC1 had close matches, although the former grouped with other Dothideomycete reductases, while the latter grouped with mostly non-Dothideomycete sequences.
OXI1 grouped with the yeast Pichia pastoris of the Saccharomycotina, while TOX9 grouped with Eurotiomycete proteins.

Overall, Toxl proteins were related to proteins of the Dothideomycetes and the Eurotiomycetes, to the Saccharomycetes (OXI1), and possibly to the Sordariomycetes (DEC1).

Finally, we have reconfirmed that the central PKS (ChPKS1 and MzmPKS1) required for $C$. heterostrophus race T T-toxin and Didymella zeae-maydis PM-toxin production are each other's closest matches and that two Toxl RED proteins (ChRED2, ChRED3) are closely related to MzmRED1, which is required for PM-toxin production. This relationship is appealing, as these proteins are involved in production of two structurally and biologically similar polyketide toxins with the same host specificity. As best we can determine, Didymella zeae-maydis does not have orthologs of ChPKS2 or any of the other proteins required for T-toxin production.

\section{Repeats are associated with Tox1 gene flanks.}

In addition to a tendency for the flanking regions of the Toxl genes to be A+T rich (Fig. 1), they are replete with repeats. To illustrate this, inverted, dyad, and direct repeats were identified and mapped on contigs carrying ChPKS1 and its closest $P K S$ gene matches (Fig. 6, Supplementary Table $6)$. We note that the intergenic regions of the $C$. heterostrophus Toxl and the MzmPKS1 genes have a greater number of repeats per kilobase than non-Toxl associated intergenic regions, such as those around $C$. heterostrophus PKS7, the Delitschia winteri PKS1 gene, and the two T. stipitatus PKS genes.

Remnants of reverse transcriptases, retrotransposons, transposases, pogo transposable elements, and integrase core domains were also found on contigs $4 \mathrm{LU}$ and $3 \mathrm{PL}$.

Table 2. Mapping Toxl gene mutations

\begin{tabular}{|c|c|c|c|c|}
\hline \multicolumn{2}{|c|}{ Parental genotype } & \multicolumn{2}{|c|}{ Progeny phenotype } & \multirow[b]{2}{*}{ Conclusions $^{\mathbf{e}}$} \\
\hline Parent $1^{a}$ & Parent $2^{b}$ & HygB $^{R}:$ HygB $^{\text {S c }}$ & Tox $^{-}:$Tox $^{+d}$ & \\
\hline $\begin{array}{l}\mathrm{PC} 161, \text { red2;MAT1-2;HygB } \\
\mathrm{PC} 161, \text { red2;MAT1-2;HygB } \\
\mathrm{PC} 161, \text { red2;MAT1-2;HygB }\end{array}$ & $\begin{array}{l}\text { C5, tox } 1 ; M A T 1-1 \\
\mathrm{C} 9, \text { TOX1;MAT1-1 } \\
\mathrm{PC} 8, \text { pks } 1 ; M A T 1-1 ; \text { Hyg }^{R}\end{array}$ & $\begin{array}{l}26: 24 \\
28: 22 \\
40: 10\end{array}$ & $\begin{array}{l}50: 0 \\
28: 22 \\
47: 3^{f}\end{array}$ & Unlinked to Tox $1 A$, maps to Tox $1 B$ \\
\hline $\begin{array}{l}\mathrm{PC} 165, \text { red } 3 ; M A T 1-2 ; H y g B^{R} \\
\mathrm{PC} 165, \text { red } 3 ; \text { MAT1-2;HygB } \\
\mathrm{PC} 165, \text { red3;MAT1-2;HygB }\end{array}$ & $\begin{array}{l}\mathrm{C} 5, \text { tox } 1 ; M A T 1-1 \\
\mathrm{C} 9, \text { TOX1;MAT1-1 } \\
\mathrm{PC} 8, \text { pks } 1 ; M A T 1-1 ; \text { Hyg }^{R}\end{array}$ & $\begin{array}{l}25: 25 \\
22: 28 \\
34: 16\end{array}$ & $\begin{array}{l}50: 0 \\
22: 28 \\
34: 16\end{array}$ & Unlinked to Tox $1 A$, maps to Tox $1 B$ \\
\hline 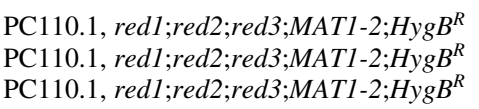 & $\begin{array}{l}\mathrm{C} 5, \text { tox } 1 ; \text { MAT1-1 } \\
\mathrm{C} 9, \text { TOX1;MAT1-1 } \\
\mathrm{PC} 8, \text { pks } 1 ; \text { MAT1-1;HygB }\end{array}$ & $\begin{array}{l}27: 23 \\
20: 30 \\
31: 19\end{array}$ & $\begin{array}{l}50: 0 \\
20: 30 \\
31: 19\end{array}$ & Unlinked to Tox $1 A$, maps to Tox $1 B$ \\
\hline $\begin{array}{l}\text { PC185, oxi1;MAT1-2;HygB } \\
\text { PC185, oxi1;MAT1-2;HygB } \\
\text { PC185, oxi1;MAT1-2;HygB } \\
\text { PC185, oxi1;MAT1-2;HygB }\end{array}$ & $\begin{array}{l}\mathrm{C} 5, \text { tox } 1 ; \text { MAT1-1 } \\
\mathrm{C} 9, \text { TOX1;MAT1-1 } \\
\mathrm{PC} 8, \text { pks } 1 ; \text { MAT1-1;HygB } \\
\text { PC13, dec1;MAT1-1;HygB }\end{array}$ & $\begin{array}{l}28: 22 \\
22: 28 \\
50: 0 \\
37: 13\end{array}$ & $\begin{array}{l}50: 0 \\
21: 29 \\
50: 0 \\
37: 13\end{array}$ & $\begin{array}{l}\text { Linked to Tox } 1 A \\
\text { Unlinked to Tox } 1 B \text {, maps to Tox } 1 A\end{array}$ \\
\hline $\begin{array}{l}\mathrm{PC} 249, \operatorname{tox} 9 ; M A T 1-2 ; H y g B^{R} \\
\mathrm{PC} 249, \operatorname{tox} 9 ; M A T 1-2 ; H y g B^{R} \\
\mathrm{PC} 249, \operatorname{tox} 9 ; M A T 1-2 ; H y g B^{R} \\
\mathrm{PC} 249, \operatorname{tox} 9 ; M A T 1-2 ; H y g B^{R}\end{array}$ & $\begin{array}{l}\mathrm{C} 5, \text { tox } 1 ; M A T 1-1 \\
\mathrm{C} 9, \text { TOX1;MAT1-1 } \\
\mathrm{PC} 8, \text { pks } 1 ; \text { MAT1-1;HygB } \\
\text { PC13, dec1;MAT1-1;HygB }\end{array}$ & $\begin{array}{l}29: 21 \\
20: 30 \\
50: 0 \\
39: 11\end{array}$ & $\begin{array}{l}50: 0 \\
20: 30 \\
50: 0 \\
39: 11\end{array}$ & $\begin{array}{l}\text { Linked to Tox } 1 A \\
\text { Unlinked to Tox } 1 B \text {, maps to Tox } 1 A\end{array}$ \\
\hline $\begin{array}{l}\text { PC44, oxi1; tox 9;MAT1-2;Hyg } B^{R} \\
\text { PC44, oxi1;tox9;MAT1-2;HygB } \\
\text { PC44, oxi1;tox9;MAT1-2;HygB } \\
\text { PC44, oxi1;tox9;MAT1-2;HygB }\end{array}$ & $\begin{array}{l}\mathrm{C} 5, \text { tox } 1 ; \text { MAT1-1 } \\
\mathrm{C} 9, \text { TOX1;MAT1-1 } \\
\mathrm{PC} 8, \text { pks } 1 ; \text { MAT1-1;HygB } \\
\text { PC13, dec1;MAT1-1;HygB }\end{array}$ & $\begin{array}{l}22: 28 \\
24: 26 \\
38: 0 \\
55: 23\end{array}$ & $\begin{array}{l}50: 0 \\
24: 26 \\
38: 0 \\
55: 23\end{array}$ & $\begin{array}{l}\text { Linked to Tox } 1 A \\
\text { Unlinked to Tox } 1 B \text {, maps to Tox } 1 A\end{array}$ \\
\hline $\begin{array}{l}\text { PC282, lam } 1 ; M A T 1-2 ; H y g B^{R} \\
\text { PC282, lam1;MAT1-2;HygB } \\
\text { PC282, lam1;MAT1-2;HygB } \\
\text { PC282, lam1;MAT1-2;HygB }\end{array}$ & $\begin{array}{l}\text { C5, tox } 1 ; M A T 1-1 \\
\text { C9, TOX1;MAT1-1 } \\
\text { PC8, pks 1;MAT1-1;HygB } \\
\text { PC13, dec1;MAT1-1;HygB }\end{array}$ & $\begin{array}{l}26: 24 \\
21: 29 \\
50: 0 \\
41: 9\end{array}$ & $\begin{array}{l}50: 0 \\
21: 29 \\
50: 0 \\
39: 11\end{array}$ & $\begin{array}{l}\text { Linked to Tox } 1 A \\
\text { Unlinked to Tox } 1 B \text {, maps to Tox } 1 A\end{array}$ \\
\hline
\end{tabular}

${ }^{\text {a }}$ All tox $1^{-}$mutations in these strains were made in a PC4(C4) TOX1;MAT1-2 genetic background.

${ }^{\mathrm{b}} \mathrm{C} 5$ is a wild-type (WT) tox 1 strain $\left(\right.$ tox $\left.^{-}\right)$, C9 is a WT TOX1 strain (tox ${ }^{+}$), PC8 is a Tox1A, tox mutant, while PC13 is a Tox1B, tox $x^{-}$mutant.

${ }^{c}$ None of the obtained ratios differed significantly from the expected ratios using a chi square test with $5 \%$ significance level.

${ }^{\mathrm{d}}$ As determined by the microbial assay (Ciuffetti et al. 1992). Tox ${ }^{+}=$like WT C9. Tox ${ }^{-}=$no halo, like C5, or reduced halo typical of particular mutant.

${ }^{\mathrm{e}}$ For each cross type, 1:1 segregation of $\mathrm{HygB}^{\mathrm{R}}: \mathrm{HygB}^{\mathrm{S}}$ indicates single-site insertion of the HygB cassette and $1: 1$ segregation of $\mathrm{Tox}^{-}: \mathrm{Tox}^{+}$indicates insertion of HygB at the known Toxl locus.

${ }^{\mathrm{f}}$ For these crosses, the ratio of Tox $^{-}$to Tox ${ }^{+}$is not as expected (3:1). We do not have an explanation for the off ratio. 


\section{Scaffold 4FP \\ PKS1}

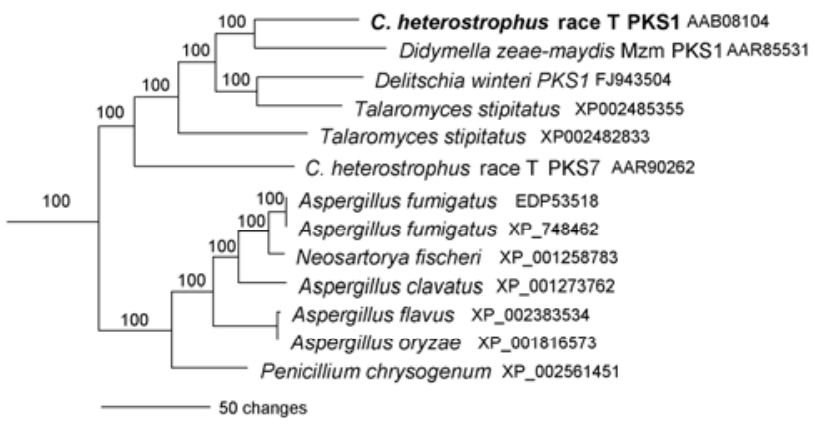

Scaffold 4LU

PKS2

LAM1
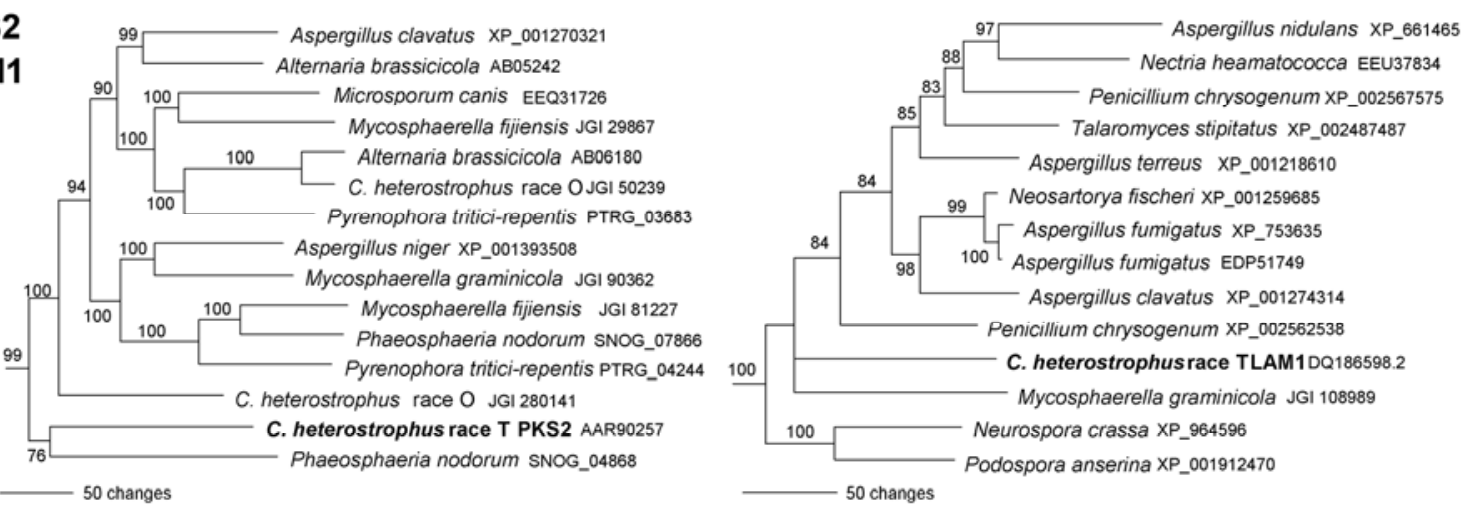

\section{Scaffold 3PL}
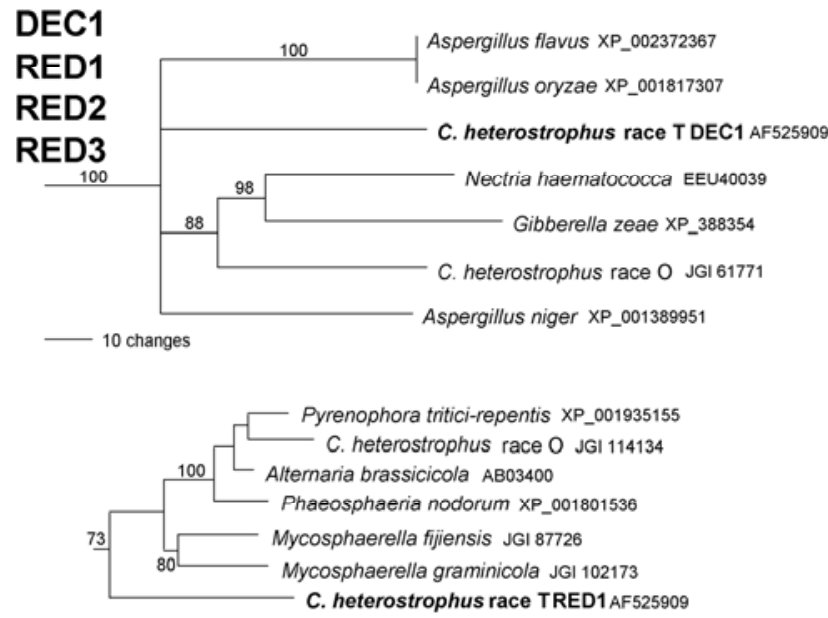

-5 changes

\section{Scaffold OXI1/TOX9 \\ OXI1 \\ TOX9}
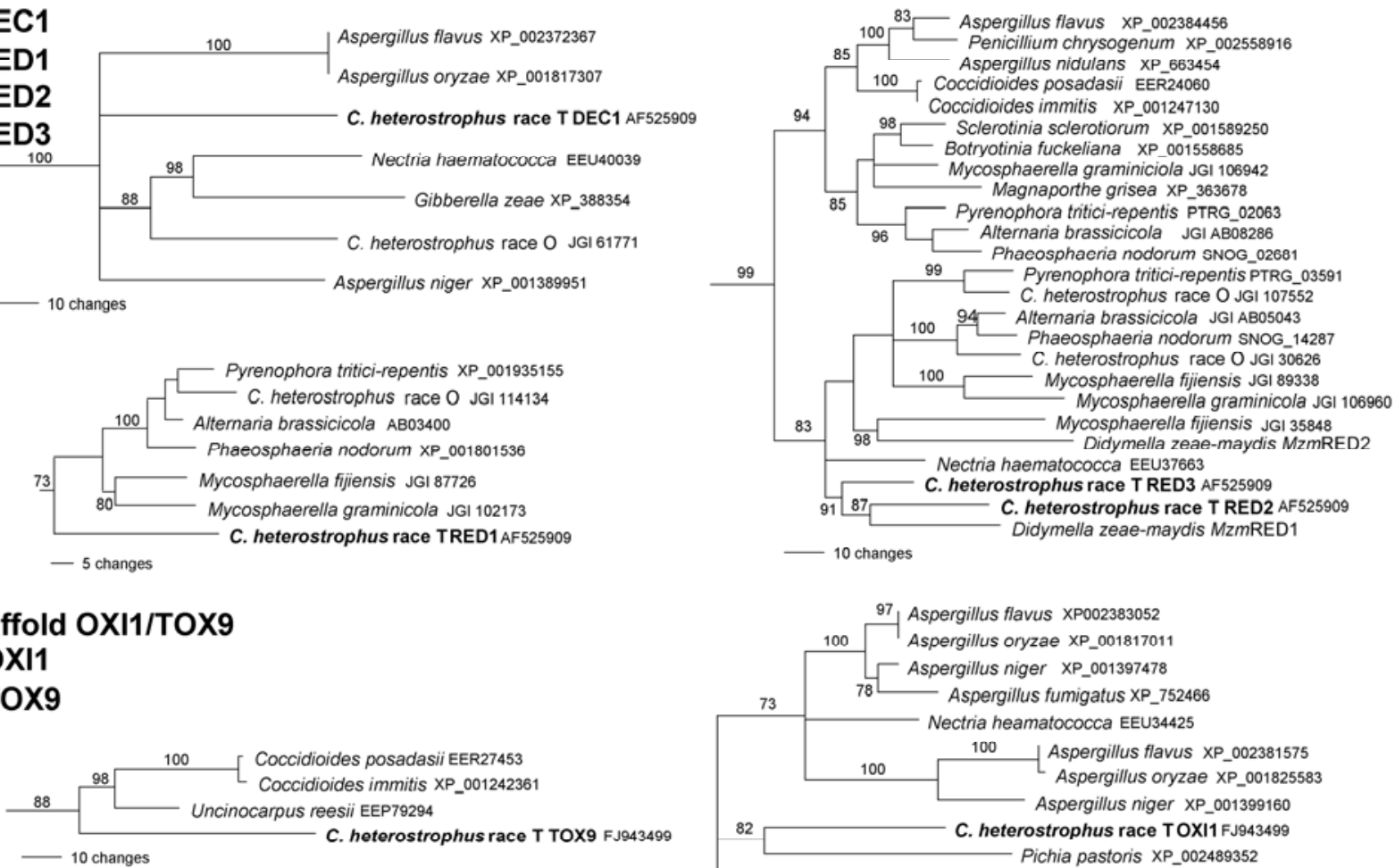

- 10 changes

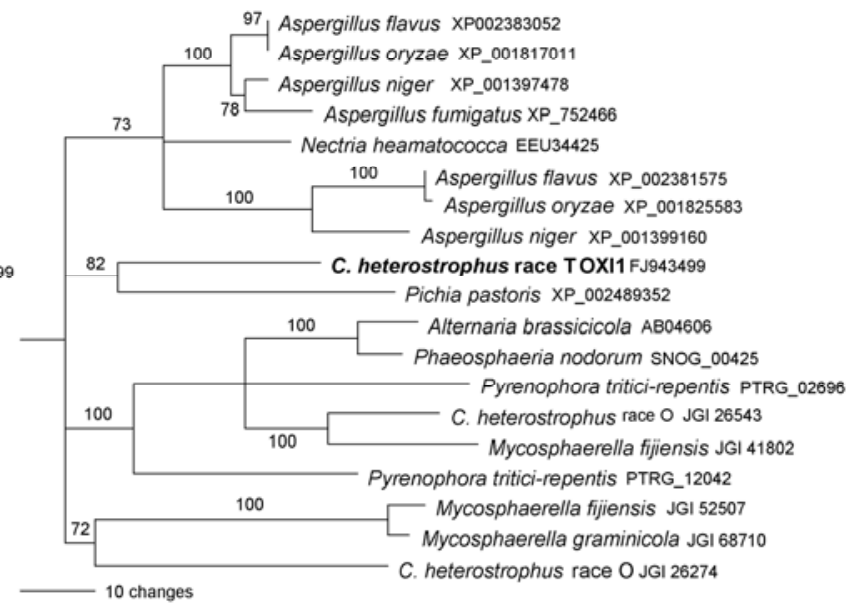

Fig. 5. Partial, unrooted, phylogenetic trees showing the position of the respective Toxl gene-inferred protein domains and relatives. Cochliobolus heterostrophus race T sequences are in bold. Accession numbers are from GenBank or the JGI genome databases. Numbers represent Bayesian support values. Branch lengths are proportional to changes, scale bars are below each tree. 


\section{DISCUSSION}

Almost 40 years after the SCLB epidemic, many details related to the cause of the epidemic have been exposed, but understanding of the genetic requirements for and the biosynthesis of T-toxin is still incomplete. The evolutionary origin of the Toxl genes remains enigmatic and increasingly intriguing.

\section{Tox1 locus structure.}

T-toxin, a family of linear polyketides produced by race $\mathrm{T}$, requires genes at two unlinked loci, ToxlA and ToxlB. Previously, we showed that three genes were required for biosynthesis, PKS1 and PKS2, both encoding PKS mapping to ToxlA, and $D E C 1$, encoding a decarboxylase mapping to Tox $1 B$. In this report, we demonstrate that six additional genes are involved. As found for all previously characterized Toxl genes, each of the new genes is unique to race T. Of the six genes, five encode dehydrogenases ( $L A M 1$, OXI1 at ToxlA, and $R E D 1, R E D 2$ and $R E D 3$ at Tox $1 B$ ), and the sixth encodes an unknown protein. The genes are not in a single cluster but, rather, occur singly or in small groups on four different, $\mathrm{A}+\mathrm{T}$ rich contigs measuring 5,129 to 19,137 bp in length. The Toxl ORF themselves are not $\mathrm{A}+\mathrm{T}$ rich, ranging in $\mathrm{G}+\mathrm{C}$ content from 50 to $54 \%$ (PKS1, PKS2, LAM1, DEC1, OXI1, TOX9) to slightly higher for the three reductase genes (RED1, RED2, $R E D 3$ with 56 to approximately $60 \% \mathrm{G}+\mathrm{C}$ and 40 to $44 \%$ $\mathrm{A}+\mathrm{T})$. The physical placement of the four fragments of known sequence, with respect to each other within the $1.2 \mathrm{Mb}$ of DNA associated with race $\mathrm{T}$, is still unknown, although inseparable genetically from the breakpoints of the associated reciprocal translocation (Baker et al. 2006; Kodama et al. 1999; Rose et al. 2002; Tzeng et al. 1992; Yang et al. 1996).

\section{Gene deletions and effects}

on T-toxin production and virulence.

Involvement of the new genes in T-toxin production was evaluated using two types of assay, a microbial, T-toxin sensitive Escherichia coli assay (Ciuffetti et al. 1992) and corn leaf whorl and spray inoculations. Results among the three screening methods largely agreed. tox9 mutants failed to inhibit bacterial growth and, with the exception of one leaf among many inoculated, did not elicit the characteristic yellow streaking on susceptible corn, indicating a central role for the TOX 9 product in T-toxin synthesis. oxil mutants produced slightly smaller bacterial inhibition zones than the wild-type but produced wild-type levels of streaking on susceptible corn, indicating that, without $O X I 1$, T-toxin production is only slightly reduced. laml transformants inconsistently produced small bacterial inhibition zones but had gray lesions and streaking symptoms on corn, indicating a role in T-toxin production. Deleting $R E D 1, R E D 2$, and $R E D 3$ separately reduced T-toxin levels to different degrees. However, T-toxin was eliminated when all three were deleted together or when either $R E D 1$ or $R E D 3$ were deleted with RED2. Concurrent deletion of RED1 and RED3 did not completely eliminate T-toxin, indicating a central function of the product of RED2. RED1 was previously evaluated by Rose and associates (2002), who observed that symptoms caused by redl mutants on susceptible corn were indistinguishable from wild type. Our corn assays agree with this conclusion, but the E. coli assay consistently produced smaller halos than the wild type, indicating reduced production of T-toxin in redl mutants.

\section{Evolutionary origin of Tox1 genes.}

The evolutionary origin of the Toxl genes remains enigmatic. The T-toxin genes are not tightly clustered but appear to be little 'islands' in a sea of A+T-rich sequences mapping to two unlinked loci, ToxlA and ToxlB. Three so-far-unconnected contigs (4FP, 4LU, and OXI/TOX9) map to ToxlA, while one, 3PL, maps to Tox $1 B$. These Toxl scaffolds comprise only a fraction (approximately $54 \mathrm{~kb}$, less than $5 \%$ ) of the $1.2 \mathrm{Mb}$ of race $\mathrm{T}-$ specific DNA distinguishing the race $\mathrm{T}$ from the race $\mathrm{O}$ genome.

Earlier, we hypothesized a horizontal origin of Toxl (Rose et al. 2002; Yang et al. 1996), mostly based on the absence in race $\mathrm{O}$ and other Cochliobolus species. Since then, phylogenomic analyses of $P K S$ genes have revealed that this type of gene is fast-evolving and highly discontinuously distributed in fungal genomes, likely as a result of multiple duplications, deletions, and recombinations (Khaldi et al. 2008; Kroken et al.

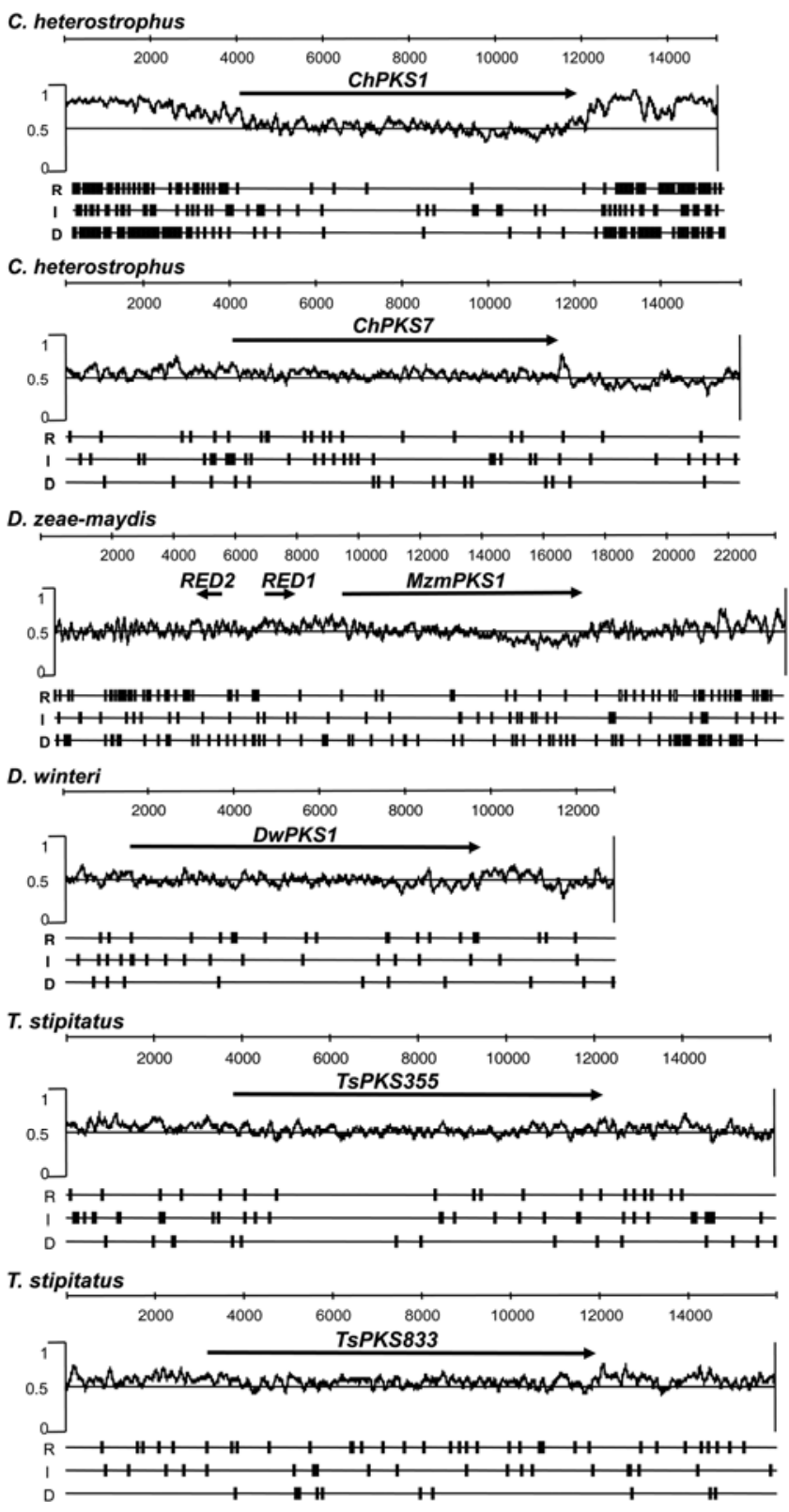

Fig. 6. Maps showing $\mathrm{A}+\mathrm{T}$ rich and repeated nature of genome regions flanking Cochliobolus heterostrophus PKS1 compared with those of phylogenetically close relatives. Scale above each map is in kilobases. Arrows indicate genes. Scale to the left of each map is $\% \mathrm{~A}+\mathrm{T}$, with a value of ' 1 ' indicating $100 \% \mathrm{~A}+\mathrm{T}$. $\mathrm{R}=$ direct, $\mathrm{I}=$ inverted, $\mathrm{D}=$ dyad repeats. $C$. heterostrophus PKS1 and Didymella zeae-maydis PKS1 (MzmPKS1) are striking in terms of repeats in flanking regions, compared with the $D e$ litschia winteri, Talaromyces stipitatus, and C. heterostrophus PKS7 (a $P K S$ with no T-toxin association) regions. 
2003). In addition, we know that there are ancestral $P K S$ genes in the fungal lineage with all possible reducing enzymatic domains (Kroken et al. 2003). These findings prompted us to reconsider our earlier hypothesis and to suggest that the Toxl $P K S$ genes are no different from other $P K S$ genes in terms of their discontinuous distribution and rapid divergence and that, given the ancestral capability, there may be no reason to invoke horizontal transfer (Kroken et al. 2003). Here, we reexamined this issue, using phylogenetic analyses to detect possible donor lineages for the nine known Toxl genes among GenBank deposits and among the recently sequenced genomes of $C$. heterostrophus relatives in the Dothideomycetes, i.e., Alternaria brassicicola, Mycosphaerella graminicola, Mycosphaerella fijiensis, Pyrenophora tritici-repentis, and Phaeosphaeria nodorum, as well as $C$. heterostrophus race O. In terms of whether genes on the same scaffolds show the same phylogenetic relationships, PKS1 is the only gene on the $15-\mathrm{kb}$ contig 4FP and, as noted above, groups most closely with two other Dothideomycete $P K S$ genes and one $T$. stipitatus $P K S$. For the two genes on the $19-\mathrm{kb}$ contig 4LU, PKS2 groups most closely with a Phaeosphaeria nodorum $P K S$ in a well-supported group of Dothideomycete $P K S$ genes, while $L A M 1$, about $1.5 \mathrm{~kb}$ away, has no close match. For the OXI1/TOX9 contig, neither gene groups with other Dothideomycete genes, nor do they have the same phylogenetic profile. At Tox $1 B$, all three $R E D$ genes group with Dothideomycete genes (also, RED2 and RED3 are related but neither is related to $R E D 1$ ), while $D E C 1$ groups with genes from a diverse group of ascomycetes but has no close match.

PCR screening of approximately 90 different Dothideomycete species with specific Toxl gene primers resulted in the discovery of a paralog of ChPKS1 and MzmPKS1 in Delitschia winteri, a distant relative of $C$. heterostrophus. The Delitschia winteri PKS1 is of similar length to C. heterostrophus PKS1, has the same six functional domains, and shares three of its five introns, but is most closely related to a T. stipitatus $P K S$ of the Eurotiomycetes and is, thus, not the donor lineage for the C. heterostrophus PKS1. The absence of PKS1 PCR bands in any Cochliobolus species with those primers shows with almostabsolute certainty that PKS1 is absent and might be suggestive of horizontal transfer were it not for the fact that $P K S$ genes have a distinctive genome signature (fast-evolving, often in mutable locations such as telomeric regions and, almost without fail, a discontinuous taxonomic distribution). Conclusive proof for a horizontal origin would be provided by the identification of a highly similar PKS1 ortholog in a distant species that, in phylogenetic analyses, would be more closely related to ChPKS1 than expected by a species phylogeny. An example for this is ToxA in the wheat pathogens Pyrenophora triticirepentis and Phaeosphaeria nodorum; ToxA of the two species is $99.7 \%$ identical, whereas the intergenic transcribed spacer region is only about $80 \%$ similar (Friesen et al. 2006).

\section{T-toxin biochemistry.}

T-toxin is a linear polyketide chain with a defined pattern of side groups in various states of reduction. Both PKS1 and PKS2 appear to have all the reducing domains necessary for generating a polyketide with the T-toxin pattern of reduction (Baker et al. 2006), such that the role of the new T-toxin gene products is not readily apparent and awaits biochemical analysis of the mutants.

None of the six additional required genes is related to any well-characterized gene, although several encode putative dehydrogenases that might be involved in reduction steps similar to enzymes of aflatoxin and lovastatin synthesis (Kennedy et al. 1999; Yabe and Nakajima 2004) that act after polyketide processing (Hutchinson et al. 2000; Yabe and Nakajima 2004).
The putative function of product of the TOX 9 gene is completely unclear, although obviously central. If we base possibilities on similarities to enzymes of well-characterized polyketide biosynthetic pathways, we speculate that it could be involved in joining of the two polyketide products produced by PKS1 and PKS2. However, Reeves and associates (2008) showed that the two PKS of hypothemycin synthesis expressed in yeast were sufficient for the production of the polyketide backbone, suggesting that one PKS uses the intermediary produced by the other as a starter unit, as we have suggested before (Baker et al. 2006). Another possibility for TOX9 function is as a regulator, but this may be less likely since it is not related to any characterized transcription factor. Note that, at this juncture, we have not identified any gene with a putative Tox1 regulatory function. A third possibility is that TOX9 assists in an unknown way in PKS function analogously to LovC, which is associated with one of the PKS involved in lovastatin synthesis and contributes differential ER activity during chain elongation (Kennedy et al. 1999). However, LovC and TOX9 are unrelated, and LovC carries an ER domain, while TOX9, as noted, lacks any known domain. We remain in the position we were in in 2006 (Baker et al. 2006), when we speculated on how the two PKS might act together to produce the carbon chain and suggested that the proposed mechanism for joining the two T-toxin polyketides must be different from that required for the lovastatin pathway. The structure of T-toxin suggests that the two polyketides produced by PKS1 and PKS2 are joined via a carbon-carbon bond, not by an ester bond as in lovastatin. One of the PKS could synthesize a precursor, used subsequently by the other PKS as a starter unit, as suggested above.

Whether additional genes are required for T-toxin synthesis is unknown. We look forward to comparing race $\mathrm{O}$ and race $\mathrm{T}$ genomes once the results of deep sequencing of the race $\mathrm{T}$ genome, currently underway at JGI, are available.

\section{MATERIALS AND METHODS}

\section{Fungal strains used and growing conditions.}

All fungal strains used in this study are provided in Table 1. Near-isogenic laboratory strains C4 $\left(\right.$ Tox $^{+} ;$MAT1-2, American Type Culture Collection [ATCC] number 48331) and C5 (Tox1 $1^{-}$;MAT1-1, ATCC number 48332) (Leach et al. 1982a) were used as the primary Tox $I^{+}$and Tox $1^{-}$strains for functional studies and for the LEAD procedure (Li et al. 2002). Toxl gene-deletion strains in the $\mathrm{C} 4$ genetic background were generated in this study.

Fungal strains were stored at $-80^{\circ} \mathrm{C}$ (Turgeon et al. 1985), in liquid CMX medium (Tzeng et al. 1992) containing 25\% glycerol (vol/vol) and were transferred anew onto CMX medium for each experiment. CMX medium is CM (Leach et al. 1982a) with xylose instead of glucose. The micronutrient stock was prepared to twice the concentration used by Sanderson and Srb (1965) and, thus, only half as much as stated by Leach and Yoder (1982a) was added to the medium. Ammonium molybdate tetrahydrate (Sigma-Aldrich, St. Louis) was used instead of sodium molybdate. The micronutrient solution was stored protected from light at room temperature, as were solutions A and B (Leach et al. 1982a). Fungi were grown under blacklights (Leach et al. 1982a) to optimize conidiation, at approximately $20^{\circ} \mathrm{C}$. For accelerated growth, fungi were placed at $30^{\circ} \mathrm{C}$. Water agar was $20 \mathrm{~g}$ of agar per liter of distilled water.

\section{DNA extraction, PCR, cloning, sequencing, and chromosome walking.}

DNA was extracted using a standard phenol and chloroform protocol (Sambrook et al. 1989). PCR reactions were performed 
with Takara LaTaq polymerase (Takara Mirus Bio, Inc., Madison, WI, U.S.A.), Promega PCR mastermix (Promega Corp., Madison, WI, U.S.A.) and Bio-Rad iProof high fidelity DNA polymerase (Bio-Rad Laboratories, Inc., Hercules, CA, U.S.A.) according to the manufacturers' instructions. For cloning PCR products, a TOPO TA cloning kit with a pCR2.1-TOPO vector and One Shot TOP10 chemically competent cells were used (Invitrogen Corp., Carlsbad, CA, U.S.A.), according to the instructions, except that reactions were scaled down to one half of the suggested volumes.

PCR products were purified by sodium acetate precipitation and were sequenced at the Cornell University Life Sciences Core Laboratories Center on an Applied Biosystems Automated 3730 DNA Analyzer using Big Dye Terminator chemistry and AmpliTaq-FS DNA polymerase (Applied Biosystems, Foster City, CA, U.S.A.).

For chromosome walking, a Vectorette starter kit (SigmaGenosys, The Woodlands, TX, U.S.A.) with restriction enzymes from New England Biolabs, Inc. (Ipswich, MA, U.S.A.) was used, following the manufacturers' instructions, except that reactions were scaled down to one third of the suggested volumes.

\section{PCR screening of scaffold assemblies.}

The genome $C$. heterostrophus $\mathrm{C} 4$ was sequenced by Celera Genomics for the former TMRI/Syngenta. Blast searches against the assembly (four to five times coverage) were done at TMRI, using Toxl genes identified as of 2002 (PKS1, PKS2, $D E C 1, R E D 1)$. Three scaffolds were identified, 4FP, 4LU, and 3PL, measuring 23,099, 30,397, and 43,533 bp, respectively (Asvarak 2003). PCR reactions were used to check the scaffold and internal contig assemblies; primer sequences, primer maps, and PCR conditions used are available upon request.

\section{Identification of the $O X I 1$ and TOX9 genes.}

The LEAD datasets of Baker and associates (2006) were reanalyzed using the network BLAST (Altschul et al. 1997) program blastcl3 of the blast-2.2.15 package downloaded from GenBank. The blastx and nr options were selected, to compare all possible amino-acid translations of the LEAD fragments with the protein sequences from the nonredundant DNA database at GenBank. Out of 68 LEAD fragments that were present in race $\mathrm{T}$ but absent in race $\mathrm{O}, 53 \mathrm{did}$ not correspond to already known T-toxin genes (data not shown). Nineteen fragments were selected for PCR screening, as these were of likely fungal origin, had e-values smaller than $\mathrm{e}^{-3}$, and were longer than $100 \mathrm{bp}$ (available upon request). PCR primers were designed to match the ends of the fragments and used with genomic DNA of race $\mathrm{T}$, strain $\mathrm{C} 4$, and race $\mathrm{O}$ DNA strain $\mathrm{C} 5$ (primers available upon request). Only one fragment, L3.1, was detected in race $T$ that was absent in race $O$. The other 18 fragments were present in both race $\mathrm{T}$ and race $\mathrm{O}$ and were not investigated further.

LEAD fragment L3.1 was used as an anchor to expand DNA sequence coverage. Reverse chromosome-walking primer pair L31vf/L31vf2 was designed and yielded an approximately 3kb fragment with the HindIII Vectorette library. This fragment was sequenced with primers L31Vf2, L31Vf3, L31Vff4, L31Vff5, L31Vff6, and L31Vr1, L31Vfr2, L31Vfr3, L31Vfr4, and the Vectorette kit primer Vec3. In the forward direction, chromosome-walking primer pair L31vr/L31vr2 yielded an approximately $1.5-\mathrm{kb}$ PCR product with the HindIII vectorette library, which was sequenced with Vec3, L31Vrf1, L31Vrf2, L31vrf3 and L31Vr2, L31Vrr3, L31Vrr4, L31Vrr5. The L31vf/L31vf2 product was then extended with chromosomewalking primer pair Oxr1/Oxr2, yielding an approximately 750-bp PCR product with the BamHI library, which was se- quenced with OxR2 and Vec3. On L31vr/L31vr2 sequence from above, Vectorette primer pair Ox2r1/Ox2r2 yielded an approximately 500-bp PCR product with the HindIII library and was sequenced with primers Ox2r2 and Vec3. To complete continuous forward and reverse coverage, primer pair DufF/ DufR was used for PCR and sequencing. Primer sequences and PCR conditions are available upon request.

\section{Gene deletion construct generation.}

Transforming constructs carrying the hygB gene for resistance to hygromycin B were generated employing the splitmarker approach (Catlett et al. 2003), using hygromycin B forward and reverse primers NLC37 and NLC38 together with C. heterostrophus-specific primers (Supplementary Tables 1 and 2).

The construct carrying the bar gene for phosphinothricin selection was made according to Robbertse and associates (2003), using primers M13f/M13r to amplify the bar gene plus promoter from $\mathrm{pBG}$ (Straubinger et al. 1992). The C. heterostrophus RED3 flanks were amplified using primer pairs R3barF1/R3barR1M13 and R3barF2M13/R3barR2, were fused to the M13f/M13r product using R3barF1/M13f and R3barR2/ M13r, and were stitched together with the internal R3barF1i/ R3barR2i. The PCR product of correct size was cloned and PCR-amplified with R3barF1i/R3barR2i and were used for transformation.

\section{Transformations.}

For all transformations with the hygB selectable marker, strain C4 (PC4; Tox $1^{+} ;$Hyg $^{S}$ ) (Leach et al. 1982a) was used. For transformation with the phosphinothricin selectable marker, C. heterostrophus PC157 ( red1;HygB $B^{S}$ was used. Transformations were as described by Turgeon and associates $(1985,1987)$, with the following alterations. Approximately 9 $\mathrm{cm}^{2}$ of a CMX agar plate was inoculated with dense fungal glycerol stock from the $-80^{\circ} \mathrm{C}$ freezer and was incubated overnight at $30^{\circ} \mathrm{C}$. The agar overgrown with mycelium was cut into small pieces, was transferred into two flasks, each with $200 \mathrm{ml}$ of liquid CMX medium, and was incubated overnight with shaking at 100 to $200 \mathrm{rpm}$ at room temperature. Mycelium and medium were homogenized in a blender and were returned to the shaker. After no more than $12 \mathrm{~h}$, the recovered mycelium pellets were transferred to $80 \mathrm{ml}$ of enzyme osmoticum containing $1.6 \mathrm{ml}$ of glucanex (in liquid preparation; provided by C. M. Hjort, Novo Nordisk, Bagsvaerd, Denmark) and $0.8 \mathrm{~g}$ of Driselase (InterSpex Products, Inc., San Mateo, CA, U.S.A. or Sigma-Aldrich) and were incubated at $30^{\circ} \mathrm{C}$ for $2 \mathrm{~h}$ with sporadic manual shaking. Protoplasts were filtered through two layers of cheesecloth and were precipitated, using a Sorvall SS-34 rotor (Thermo Fisher Scientific, Inc., Waltham, MA, U.S.A.), for $6 \mathrm{~min}$ at $5,000 \mathrm{rpm}$ at $4{ }^{\circ} \mathrm{C}$. Protoplasts were washed and suspended in a total volume of $1.5 \mathrm{ml}$ of sorbitol, Tris, and calcium buffer (containing 50 instead of $10 \mathrm{mM}$ $\mathrm{CaCl}_{2}$ ) and were kept on ice. Protoplast yield was $1 \times 10^{7}$ to 2 $\times 10^{7}$ protoplasts per milliliter. For transformation, 1 to $1.5 \mu \mathrm{g}$ of each ethanol-sodium-acetate precipitated (Sambrook et al. 1989) split-marker PCR product in 1 to $3 \mu$ of $\mathrm{H}_{2} \mathrm{O}$ was added to $100 \mu \mathrm{l}$ of protoplast suspension and was incubated for 2 to $10 \mathrm{~min}$ on ice. Polyethylene glycol (with 50 instead of $10 \mathrm{mM}$ $\mathrm{CaCl}_{2}$ ) was added in three aliquots to the protoplast suspension, which was incubated for 2 to $10 \mathrm{~min}$ on ice and was mixed directly into 10 to $15 \mathrm{ml}$ of regeneration agar (with 1.6 instead of $2 \%$ agar; sucrose and agar solutions autoclaved separately) at $45^{\circ} \mathrm{C}$ in a petri plate. After 6 to $10 \mathrm{~h}$ at $30^{\circ} \mathrm{C}$, the plates were overlaid with 10 to $15 \mathrm{ml}$ of $1 \%$ agar with hygromycin B (EMD Biosciences, Inc., San Diego, CA, U.S.A.), to a final hygromycin B plate concentration of $50 \mu \mathrm{g} / \mathrm{ml}$, and 
were incubated for 3 to 5 days at $30^{\circ} \mathrm{C}$. Putative transformants were transferred to CMX plates, were single-conidia purified, and were tested for hygromycin $\mathrm{B}$ resistance, prior to PCR screening for presence of insert.

For transformation with the bar marker for phosphinothricin selection, the above protocol was followed, except that $1 \mu \mathrm{g}$ of the bar construct in 1 to $3 \mu \mathrm{l}$ of $\mathrm{H}_{2} \mathrm{O}$ was added to the protoplast suspension, the regeneration agar was replaced by phosphinothricin selection agar (minimal medium [Leach et al. 1982a] with $1.6 \%$ agar, $1 \mathrm{M}$ sucrose, and no glucose; sucrose and agar solutions autoclaved separately). The selective $1 \%$ agar overlay with DL-phosphinothricin (Fisher Scientific Research, Pittsburgh, PA, U.S.A.) was applied after $13 \mathrm{~h}$, to a final phosphinothricin plate concentration of $100 \mu \mathrm{g} / \mathrm{ml}$. Putative transformants were tested for phosphinothricin resistance following single-conidia purification.

\section{Insert confirmation.}

Targeted insertion of the deletion constructs was confirmed by PCR and crosses to tester strains. PCR reactions A, B, C, and D were done for each construct (Supplementary Table 3). In PCR A, external primers 1 and 2 were outside the introduced deletion construct flanks. Marker primers 1 and 2 from PCR reactions B and C were NLC37 and NLC38, respectively, for hygromycin B selection, and bir and bif, respectively, for phosphinothricin selection. Internal primers 1 and 2 of PCR D were on the region replaced by the marker. When more than one gene was deleted, PCR D was done for each gene to prove its absence.

\section{Crosses.}

One transformant per knockout genotype was selected, and crossed with tester strains C5, C9, PC8, and PC13 (Table 1). Transformants carrying redlred2red 3 or red 2 red 3 deletions were not crossed with strain PC13, since DEC1 is linked to the $R E D$ genes. Strains carrying a single deletion of $R E D 1$ and those deleted for both REDI and RED3 were not crossed.

Crosses were done following Leach and associates (1982a), except that the corn leaf was placed on minimal medium (Leach et al. 1982a) lacking glucose, and toothpicks were used to inoculate each leaf on opposite sides equidistantly three times. At least 50 ascospores per cross were harvested after 21 days, by spreading an aqueous ascospore suspension onto water agar and transferring nine single ascospores to one CMX plate after germination. Plates were incubated at $20^{\circ} \mathrm{C}$ under blacklights for 4 to 5 days, until colonies were approximately $1.5 \mathrm{~cm}$ in diameter. Colonies were then transferred, using toothpicks, to new hygromycin $\mathrm{B}$ selection plates (CMX without solutions $\mathrm{A}$ and $\mathrm{B}$, plus $50 \mu \mathrm{g}$ of hygromycin $\mathrm{B}$ per milliliter) and LBA (LB plus ampicillin medium) plates (10 $\mathrm{g}$ of tryptone, $5 \mathrm{~g}$ of yeast extract, $5 \mathrm{~g}$ of $\mathrm{NaCl}$, and $20 \mathrm{~g}$ of agar per liter) for hygromycin sensitivity and for T-toxin assessment (described below), respectively. Hygromycin B selection plates were incubated at $30^{\circ} \mathrm{C}$ in the dark for 2 days before evaluation.

\section{Screening for T-toxin production by bacterial assay.}

T-toxin production was assessed using susceptible transgenic E. coli cells expressing the corn mitochondrial protein URF13 (Dewey et al. 1988). Assay plates (LBA) were prepared according to Ciuffetti and associates (1992), except that the bacterial suspension was added to each plate in excess and poured off, and the plate was left to dry. Agar plugs were removed from 1week-old fungal colonies grown in $15 \mathrm{~cm}$ diameter petri plates incubated at $20^{\circ} \mathrm{C}$ under blacklights. Four plugs were taken per plate, at intervals of $1 \mathrm{~cm}$ along a radial transect starting from $2 \mathrm{~cm}$ inside the colony towards the outside. The plugs were briefly dried on a paper towel and were deposited mycelium- side down onto assay plates. Controls used were wild-type strains $\mathrm{C} 4\left(\operatorname{Toxl}^{+}\right)$and $\mathrm{C} 5\left(\operatorname{Tox}^{-}\right)$. The plates were incubated at $30^{\circ} \mathrm{C}$ for $20 \mathrm{~h}$ and were stored at $4{ }^{\circ} \mathrm{C}$ until photographed. To screen cross progeny for T-toxin production, $5 \mathrm{ml}$ of bacterial suspension was added to LBA plates with progeny (described above) grown overnight at $20^{\circ} \mathrm{C}$ under blacklights, the excess was poured off, and the remainder left to dry, with incubation at $30^{\circ} \mathrm{C}$ for at least $24 \mathrm{~h}$, when bacterial inhibition zones could be observed.

\section{Screening for T-toxin production by corn leaf assay.}

All fungal strains were grown on CMX medium for 10 days. Corn varieties used were W64A-T with Tcms and the conventional male-fertile W64A-N. Plants were grown in $10 \mathrm{~cm}$ diameter pots in a growth chamber at $24^{\circ} \mathrm{C}$, and a cycle of $16 \mathrm{~h}$ of light followed by $8 \mathrm{~h}$ of darkness, until formation of the fourth persistent, foliar leaf after 18 to 22 days. Five to eight plants per pot were sprayed from a distance of approximately $30 \mathrm{~cm}$ with $4 \mathrm{ml}$ of conidium suspension $\left(5 \times 10^{4}\right.$ conidia $/ \mathrm{ml}$ in sterile water with $0.02 \% \mathrm{vol} / \mathrm{vol}$ Tween), using a Preval chromatography sprayer (Grace Davison Discovery Sciences, Columbia, MD, U.S.A.). Alternatively, two 3-cm plugs of agar bearing mycelium were placed in the whorl, which was filled with water and Tween. Plants were incubated overnight or up to $24 \mathrm{~h}$ in a mist chamber at $25^{\circ} \mathrm{C}$, and then, were returned to the growth chamber. The third and fourth leaves were collected and photographed the fourth day after inoculation.

\section{PCR screening for Tox1 orthologs.}

DNA from 101 fungal isolates representing approximately 90 different species were screened for the presence of $P K S 1$, with PCR primer pairs designed to conserved regions of the $\mathrm{KS}, \mathrm{AT}, \mathrm{ER}, \mathrm{KR}$, and ACP regions of race $\mathrm{T}$ and Didymella zeae-maydis PKS1 functional domains (GenBank accessions U68040, AY495642). Specific primer pairs to respective conserved regions of all the other eight Toxl genes described in this study and earlier studies were designed (not shown) and were used to PCR-screen 15 Cochliobolus and Bipolaris isolates. DNAs of the screened isolates were provided by C. L. Schoch, Oregon State University and P. L. Crous, Centraalbureau voor Schimmelcultures, A. Y. Rossman, United States Department of Agriculture, Beltsville, M. L. Berbee, University of British Columbia, and L. Mendoza, Michigan State University, or were from the Turgeon lab collection. Positive PCR bands were cloned and extended in both directions, using consecutive rounds of chromosome walking (details not shown).

\section{Bioinformatics.}

Candidate ORF on the Toxl scaffolds were identified using GeneQuest, part of the DNASTAR Lasergene V. 8.0.2 suite of programs. Conserved protein domains were determined by Pfam (Finn et al. 2008) or National Center for Biotechnology Information (Marchler-Bauer et al. 2007). Repeats were identified using GeneQuest, invoking functions for inverted, dyad, and direct repeat finding. Default settings were used, which included minimum length of $12 \mathrm{bp}$ for inverted repeats and minimum lengths of 12 for dyad and direct repeats.

\section{Phylogenetic analyses.}

Phylogenetic analyses were performed to find the closest relatives, if any, of the identified Toxl genes. For this, the protein signature domains corresponding to RED1, RED2, RED3, OXI1, TOX9, LAM1, DEC1, and the KS domains corresponding to PKS1 and PKS2 identified by Pfam were used as queries against the protein databases at GenBank, and the top 20 matches were retrieved for each domain. Also, the Dothideomycete genome sequences in the JGI database of Alternaria 
brassicicola, C. heterostrophus race $\mathrm{O}$, Mycosphaerella graminicola, Mycosphaerella fijiensis, Pyrenophora tritici-repentis, and Phaeosphaeria nodorum, were queried, and no more than the top two matches were retrieved, were preliminarily aligned with the GenBank matches, using Clustal X (Thompson et al. 1997), and were then manually optimized. RED2, RED3, the Didymella zeae-maydis MzRED1, and MzRED2 were all short chain dehydrogenases and were similar enough to be combined into one alignment as indicated by preliminary analyses. OXI1, also a short chain dehydrogenase, was too divergent and was analyzed separately. The datasets thus assembled had the following numbers of taxa and characters: DEC1: 22 and 142, TOX9: 35 and 149, LAM1: 30 and 324, OXI1: 33 and 97, PKS1: 35 and 434, PKS2: 33 and 412, RED1: 33 and 161, RED2, RED3, MzRED1 and MzRED2: 53 and 107. Analyses were performed using MrBayes 3.1.2 (Ronquist and Huelsenbeck 2003). Analyses were run for 500,000 generations with a gamma correction and a mixed amino acid rate matrix, sampling every 100th generation, and discarding the first 500 trees. Otherwise, default settings were used. Consensus trees were computed and visualized in PAUP* V. 4.0b10 (Swofford 2002). Clades containing Toxl domains were cropped from each tree and are displayed in Figure 5.

\section{ACKNOWLEDGMENTS}

P. Inderbitzin was supported by Natural Sciences and Engineering Research Council of Canada (NSERC) and Swiss National Science Foundation (SNSF) postdoctoral fellowships. We acknowledge the former TMRI/Syngenta/Celera partnership for access to the race $\mathrm{T}$ genome and the DOE JGI for prepublication access to six Dothideomycete genomes. C. Schoch, P. Crous, A. Rossman, M. Berbee, and L. Mendoza provided fungal DNAs and K. Loeffler expert photographic assistance.

\section{LITERATURE CITED}

Altschul, S. F., Madden, T. L., Schäffer, A. A., Zhang, J., Zhang, Z., Miller, W., and Lipman, D. J. 1997. Gapped BLAST and PSI-BLAST: A new generation of protein database search programs. Nucleic Acids Res. 25:3389-3402.

Asvarak, T. 2003. Functional analysis of genes at the Cochliobolus heterostrophus TOX1 locus and evaluation of a REMI mutant altered in conidium development. Ph.D. thesis. Cornell University, Ithaca, NY, U.S.A.

Baker, S. E., Kroken, S., Inderbitzin, P., Asvarak, T., Li, B.-Y., Shi, L., Yoder, O. C., and Turgeon, B. G. 2006. Two polyketide synthase-encoding genes are required for biosynthesis of the polyketide virulence factor, T-toxin, by Cochliobolus heterostrophus. Mol. Plant-Microbe Interact. 19:139-149.

Braun, C. J., Siedow, J. N., and Levings, C. S., III. 1990. Fungal toxins bind to the URF13 protein in maize mitochondria and Escherichia coli. Plant Cell 2:153-161.

Bronson, C. R. 1988. Ascospore abortion in crosses of Cochliobolus heterostrophus heterozygous for the virulence locus Tox1. Genome 30:12-18.

Catlett, N. L., Lee, B.-N., Yoder, O. C., and Turgeon, B. G. 2003. Splitmarker recombination for efficient targeted deletion of fungal genes. Fungal Genet. Newsl. 50:9-11.

Chang, H.-R., and Bronson, C. R. 1996. A reciprocal translocation and possible insertion(s) tightly associated with host-specific virulence in Cochliobolus heterostrophus. Genome 39:549-557.

Ciuffetti, L., Yoder, O. C., and Turgeon, B. G. 1992. A microbiological assay for host-specific fungal polyketide toxins. Fungal Genet. Newsl. 39:18-19.

Dewey, R. E., Siedow, J. N., Timothy, D. H., and Levings, C. S., III. 1988. A 13-kilodalton maize mitochondrial protein in E. coli confers sensitivity to Bipolaris maydis toxin. Science 239:293-295.

Drechsler, C. 1925. Leafspot of maize caused by Ophiobolus heterostrophus, n. sp., the ascigerous stage of a Helminthosporium exhibiting bipolar germination. J. Agric. Res. 31:701-726.

Finn, R. D., Tate, J., Mistry, J., Coggill, P. C., Sammut, J. S., Hotz, H. R., Ceric, G., Forslund, K., Eddy, S. R., Sonnhammer, E. L., and Bateman, A. 2008. The Pfam protein families database. Nucleic Acids Res. 36:D281-D288.

Friesen, T. L., Stukenbrock, E. H., Liu, Z., Meinhardt, S., Ling, H., Faris, J. D., Rasmussen, J. B., Solomon, P. S., McDonald, B. A., and Oliver,
R. P. 2006. Emergence of a new disease as a result of interspecific virulence gene transfer. Nat. Genet. 38:953-956.

Hooker, A. L. 1974. Cytoplasmic susceptibility in plant disease. Annu. Rev. Phytopathol. 12:167-179.

Hooker, A. L., Smith, D. R., Lim, S. M., and Musson, M. D. 1970. Physiological races of Helminthosporium maydis and disease resistance. Plant Dis. Rep. 54:1109-1110.

Hutchinson, C. R., Kennedy, J., Park, C., Kendrew, S., Auclair, K., and Vederas, J. 2000. Aspects of the biosynthesis of non-aromatic fungal polyketides by iterative polyketide synthases. Antonie Leeuwenhoek 78:287-295.

Kennedy, J., Auclair, K., Kendrew, S. G., Park, C., Vederas, J. C., and Hutchinson, C. R. 1999. Modulation of polyketide synthase activity by accessory proteins during lovastatin biosynthesis. Science 284:13681372.

Khaldi, N., Collemare, J., Lebrun, M. H., and Wolfe, K. H. 2008. Evidence for horizontal transfer of a secondary metabolite gene cluster between fungi. Genome Biol. 9:R18.

Kodama, M., Rose, M. S., Yang, G., Yun, S. H., Yoder, O. C., and Turgeon, B. G. 1999. The translocation-associated Tox1 locus of Cochliobolus heterostrophus is two genetic elements on two different chromosomes. Genetics 151:585-596.

Kono, Y., Takeuchi, S., Kawarada, A., Daly, J. M., and Knoche, H. W. 1981. Studies on the host-specific pathotoxins produced in minor amounts by Helmintosporium maydis, race T. Bioorg. Chem. 10:206218.

Kroken, S., Glass, N. L., Taylor, J. W., Yoder, O. C., and Turgeon, B. G. 2003. Phylogenomic analysis of type I polyketide synthase genes in pathogenic and saprobic ascomycetes. Proc. Natl. Acad. Sci. U.S.A. 100:15670-15675.

Leach, J., Lang, B. R., and Yoder, O. C. 1982a. Methods for selection of mutants and in vitro culture of Cochliobolus heterostrophus. J. Gen. Microbiol. 128:1719-1729.

Leach, J., Tegtmeier, K. J., Daly, J. M., and Yoder, O. C. 1982b. Dominance at the Toxl locus controlling T-toxin production by Cochliobolus heterostrophus. Physiol. Plant Pathol. 21:327-333.

Levings, C. S., III, Rhoads, D. M., and Siedow, J. N. 1995. Molecular interactions of Bipolaris maydis T-toxin and maize. Can. J. Bot. 73:S483-S489.

Li, B.-Y., Kwan, W. K., Turgeon, G. B., Wu, J., Wang, X., Li, E., Zhu, T., and Shi, L. 2002. Analysis of differential gene expression by ligation specificity-based transcript profiling. OMICS J. Integr. Biol. 6:175-185.

Lim, S. M., and Hooker, A. L. 1971. Southern corn leaf blight: Genetic control of pathogenicity and toxin production in race $\mathrm{T}$ and race $\mathrm{O}$ of Cochliobolus heterostrophus. Genetics 69:115-117.

Lim, S. M., and Hooker, A. L. 1972a. A preliminary characterization of Helminthosporium maydis toxins. Plant Dis. Rep. 56:805-807.

Lim, S. M., and Hooker, A. L. 1972b. Disease determinant of Helminthosporium maydis race T. Phytopathology 62:968-971.

Marchler-Bauer, A., Anderson, J. B., Derbyshire, M. K., DeWeese-Scott, C., Gonzales, N. R., Gwadz, M., Hao, L., He S., Hurwitz, D. I., Jackson, J. D., Ke, Z., Krylov, D., Lanczycki, C. J., Liebert, C. A., Liu, C., Lu, F., Lu, S., Marchler, G. H., Mullokandov, M., Song, J. S., Thanki, N., Yamashita, R. A., Yin, J. J., Zhang, D., and Bryant, S. H. 2007. CDD: A conserved domain database for interactive domain family analysis. Nucleic Acids Res. 35:D237-240.

Matthews, D. E., Gregory, P., and Gracen, V. E. 1979. Helminthosporium maydis race $\mathrm{T}$ toxin induces leakage of $\mathrm{NAD}^{+}$from $\mathrm{T}$ cytoplasm corn mitochondria. Plant Physiol. 63:1149-1153.

Mercado, A. C., Jr., and Lantican, R. M. 1961. The susceptibility of cytoplasmic male sterile lines of corn to Helminthosporium maydis Nish. \& Miy. Philipp. Agric. 45:235-243.

Reeves, C. D., Hu, Z., Reid, R., and Kealey, J. T. 2008. Genes for the biosynthesis of the fungal polyketides hypothemycin from Hypomyces subiculosus and radicicol from Pochonia chlamydosporia. Appl. Environ. Microbiol. 74:5121-5129

Robbertse, B., Yoder, O. C., Nguyen, A., Schoch, C. L., and Turgeon, B. G. 2003. Deletion of all Cochliobolus heterostrophus monofunctional catalase-encoding genes reveals a role for one in sensitivity to oxidative stress but none with a role in virulence. Mol. Plant-Microbe Interact. 16:1013-1021.

Ronquist, F., and Huelsenbeck, J. P. 2003. MRBAYES 3: Bayesian phylogenetic inference under mixed models. Bioinformatics 19:1572-1574.

Rose, M. S. 1996. Molecular genetics of polyketide toxin production in Cochliobolus heterostrophus. Ithaca, NY: Cornell University. 217 p.

Rose, M. S., Yun, S. H., Asvarak, T., Lu, S. W., Yoder, O. C., and Turgeon, B. G. 2002. A decarboxylase encoded at the Cochliobolus heterostrophus translocation-associated Tox $1 B$ locus is required for polyketide ( $\mathrm{T}$ toxin) biosynthesis and high virulence on T-cytoplasm maize. Mol. Plant-Microbe Interact. 15:883-893. 
Sambrook, J., Fritsch, E. F., and Maniatis, T. 1989. Molecular Cloning. Cold Spring Harbor Laboratory Press. Cold Spring Harbor, NY, U.S.A.

Sanderson, K. E., and Srb, A. M. 1965. Heterokaryosis and parasexuality an the fungus Ascochyta imperfecta. Am. J. Bot. 52:72-81.

Scheifele, G., Whitehead, W., and Rowe, C. 1970. Increased susceptibility to southern leaf spot (Helminthosporium maydis) in inbred lines and hybrids of maize with Texas male-sterile cytoplasm. Plant Dis. Rep. 54:501-503.

Smith, D. R., Hooker, A. L., and Lim, S. M. 1970. Physiologic races of Helminthosporium maydis. Plant Dis. Rep. 54:819-822.

Straubinger, B., Straubinger, E., Wirsel, S., Turgeon, B. G., and Yoder, O. C. 1992. Versatile fungal transformation vectors carrying the selectable bar gene of Streptomyces hygroscopicus. Fungal Genet. Newsl. 39:8283.

Swofford, D. L. 2002. PAUP*. Phylogenetic Analysis Using Parsimony (*and Other Methods). Version 4. Sinauer Associates, Sunderland, MA, U.S.A.

Tegtmeier, K. J., Daly, J. M., and Yoder, O. C. 1982. T-toxin production by near-isogenic isolates of Cochliobolus heterostrophus races $\mathrm{T}$ and $\mathrm{O}$. Phytopathology 72:1492-1495.

Thompson, J. D., Gibson, T. J., Plewniak, F., Jeanmougin, F., and Higgins, D. G. 1997. The Clustal_X windows interface: Flexible strategies for multiple sequence alignment aided by quality analysis tools. Nucleic Acids Res. 25:4876-4882.

Turgeon, B. G., and Baker, S. E. 2007. Genetic and genomic dissection of the Cochliobolus heterostrophus Tox1 locus controlling biosynthesis of the polyketide virulence factor T-toxin. Adv. Genet. 57:219-261.

Turgeon, B. G., Garber, R. C., and Yoder, O. C. 1985. Transformation of the fungal maize pathogen Cochliobolus heterostrophus using the Aspergillus nidulans amdS gene. Mol. Gen. Genet. 201:450-453.

Turgeon, B. G., Garber, R. C., and Yoder, O. C. 1987. Development of a fungal transformation system based on selection of sequences with promoter activity. Mol. Cell. Biol. 7:3297-3305.

Turgeon, B. G., Kodama, M., Yang, G., Rose, M. S., Lu, S. W., and Yoder, O. C. 1995. Function and chromosomal location of the Cochliobolus heterostrophus Tox1 locus. Can. J. Bot. 73(S1):1071-1076.

Tzeng, T.-H., Lyngholm, L. K., Ford, C. F., and Bronson, C. R. 1992. A restriction fragment length polymorphism map and electrophoretic karyotype of the fungal maize pathogen Cochliobolus heterostrophus. Genetics 130:81-96.
Ullstrup, A. J. 1970. History of southern corn leaf blight. Plant Dis. Rep. 54:1100-1102.

Ullstrup, A. J. 1972. The impacts of the southern corn leaf blight epidemics of 1970-1971. Annu. Rev. Phytopathol. 10:37-50.

Wise, R. P., Bronson, C. R., Schnable, P. S., and Horner, H. T. 1999. The genetics, pathology, and molecular biology of T-cytoplasm male sterility in maize. Adv. Agron. 65:79-130.

Wolpert, T. J., Dunkle, L. D., and Ciuffetti, L. M. 2002. Host-selective toxins and avirulence determinants: What's in a name? Annu. Rev. Phytopathol. 40:251-285.

Yabe, K., and Nakajima, H. 2004. Enzyme reactions and genes in aflatoxin biosynthesis. Appl. Microbiol. Biotechnol. 64:745-755.

Yang, G., Rose, M. S., Turgeon, B. G., and Yoder, O. C. 1996. A polyketide synthase is required for fungal virulence and production of the polyketide T-toxin. Plant Cell 8:2139-2150.

Yoder, O. C., and Gracen, V. E. 1975. Segregation of pathogenicity types and host-specific toxin production in progenies of crosses between races $\mathrm{T}$ and $\mathrm{O}$ of Helminthosporium maydis (Cochliobolus heterostrophus). Phytopathology 65:273-276.

Yoder, O. C., Yang, G., Rose, M. S., Lu, S. W., and Turgeon, B. G. 1994 Complex genetic control of polyketide toxin production by Cochliobolus heterostrophus. Pages 223-230 in: Advances in Molecular Genetics of Plant-Pathogen Interactions. M. J. Daniels, J. A. Downie, and A. E. Osbourn, eds. Kluwer Academic Publishers, Dordrecht, The Netherlands.

Yun, S. H. 1998. Molecular genetics and manipulation of pathogenicity and mating determinants in Mycosphaerella zeae-maydis and Cochliobolus heterostrophus. Ph.D. thesis. Cornell University, Ithaca, NY, U.S.A.

Yun, S. H., Turgeon, B. G., and Yoder, O. C. 1998. REMI-induced mutants of Mycosphaerella zeae-maydis lacking the polyketide PM-toxin are deficient in pathogenesis to corn. Physiol. Mol. Plant Pathol. 52:53-66.

Zhu, X. 1999. Molecular analysis of loci controlling T-toxin biosynthesis in Cochliobolus heterostrophus. Ph.D. thesis. Cornell University, Ithaca, NY, U.S.A.

\section{AUTHOR-RECOMMENDED INTERNET RESOURCES}

U. S. Department of Energy JGI website: www.jgi.doe.gov JGI Cochliobolus heterostrophus C5 webpage: genome.jgi-psf.org/CocheC5_1/CocheC5_1.home.html 